\title{
CONFLICTS BETWEEN CIVIL LAW AND COMMON LAW IN JUDGMENT RECOGNITION AND ENFORCEMENT: WHEN IS THE FINALITY DISPUTE FINAL?
}

\author{
JIE HUANG*
}

\begin{abstract}
Very little literature concerns conflicts between civil law and common law requirements for judgment recognition and enforcement (JRE) and grounds for refusing JRE. This paper intends to fill this gap by using the finality dispute between Mainland China and Hong Kong as an example. It compares relevant Chinese law, Hong Kong law, U.S. law, and EU law. It also analyzes Mainland judicial statistics from 1999 to 2010. It argues that Hong Kong courts inappropriately apply the law of the requested court to determine the finality of a Mainland judgment in the judgment recognition and enforcement proceedings. It proposes three solutions to solve the finality dispute between Mainland China and Hong Kong: amend Hong Kong law, amend Mainland law, or adopt interregional law approaches.
\end{abstract}

I. Different Criteria of "Finality" in Mainland China and

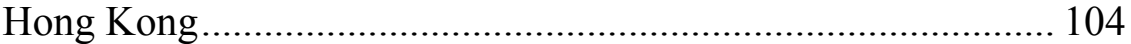

A. Criteria of "Finality" under Mainland Law ......................... 105 B. Criteria of "Finality" under Hong Kong JRE Law: Chiyu and Its Progeny ........................................................................ 111

II. Conflicts Brought by the Different Criteria of Finality......... 113

A. Problems of Chiyu ........................................................... 113

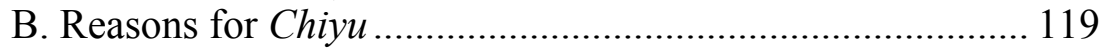

C. Malicious Re-litigations and Forum Shopping Caused by the

Chiyu Doctrine.................................................................... 125

D. The Preferable Minority Approach in Hong Kong Courts. 130

III. Proposed Solutions to the Finality Conflict ............................ 131

A. Amend Hong Kong Law................................................... 131

B. Amend the Mainland CPL …………………………......... 132

C. Interregional Law Approaches.............................................. 135

1. Provide an Autonomous Terminology for Finality .......... 135

2. Apply the Law of the Judgment-Rendering Region......... 138 
Conflicts between civil law and common law bring thorny problems in jurisdiction. ${ }^{1}$ For example, under the Brussels Convention, ${ }^{2}$ or Brussels I Regulation, ${ }^{3}$ most case law concerning conflicts between civil and common law is about jurisdiction. ${ }^{4}$ Similarly, jurisdiction raised serious controversies when a worldwide jurisdiction and judgment ${ }^{5}$ convention was negotiated in The Hague in the 1990s. ${ }^{6}$ Conflicts between civil law and common law also create disputes in cases addressing forum shopping, such as anti-suit injunctions and lis alibi pendens. ${ }^{7}$ Moreover, many authors discuss conflicts between civil law and common law in procedures, such as inquisitorial and adversarial systems, ${ }^{8}$ as well as the way of executing judgments. ${ }^{9}$ However, there is

* Jie Huang, Associate Professor of Law at Shanghai Institute of Foreign Trade School of Law, S.J.D. Duke (2010). I would like to express my sincere thanks to Professor Ralf Michaels at Duke University School of Law for his precious guidance and advice on earlier drafts of this paper. I also appreciate the support from the International Trade Law Project of Shanghai Education Commission (Project No. J51204) and Shanghai Pujiang Rencai Plan. All errors are mine and all comments are welcome. I can be reached at humilityus@gmail.com.

1 See Jonathan Harris, Understanding the English Response of the Europeanisation of Private International Law, 4 J. PRIVATE INT'L L. 347, 352 (2008); Anna Gardella \& Luca G. Radicati di Brozolo, Civil Law, Common Law and Market Integration: The EC Approach to Conflicts of Jurisdiction, 51 AM. J. COMP. L. 611, 620-24 (2003).

2 Convention of 27 September 1968 on Jurisdiction and Enforcement of Judgments in Civil and Commercial Matters, 1978 O.J. (L 304) 36 [hereinafter Brussels Convention].

3 Council Regulation 44/2001, 2001 O.J. (L 12) 1 (EC) [hereinafter Brussels I Regulation].

4 For example, see Case C-116/02, Gasser GmbH v. MISAT Srl., 2003 E.C.R. I-14693; Case C281/02, Owusu v. Jackson, 2005 E.C.R. I-01383; Case C-159/02, Turner v. Grovit, 2004 E.C.R. I-03565. For comments on these cases, see Harris, supra note 1, at 368-73; Andrew Dickinson, A Charter for Tactical Litigation in Europe?: Turner v. Grovit, 2003 LlOYD's MAR. \& COM. L.Q. 273 (2004); Adrian Briggs, Anti-Suit Injunctions and Utopian Ideals, 120 Law Q. Rev. 529 (2004).

5 In this paper judgments are restricted to civil and commercial judgments.

6 See Arthur T. von Mehren, Recognition and Enforcement of Foreign Judgments: A New Approach for the Hague Conference?, 57 LAW \& CONTEMP. PROBS., no. 3, 1994 at 271, 274-76; see also Ronald A. Brand, Due Process, Jurisdiction and a Hague Judgments Convention, $60 \mathrm{U}$. PITT. L. REV. 661 (1999); Kevin M. Clermont, Jurisdictional Salvation and the Hague Treaty, 85 CORNELl L. REV. 89 (1999); Ralf Michaels, Two Paradigms of Jurisdiction, 27 MiCH. J. INT'L L. 1003, 1064-69 (2006); Ralf Michaels, Some Fundamental Jurisdictional Conceptions as Applied in Judgment Conventions, in CONFLICT OF LAWS IN A GLOBALIZED WORLD 29, 30 (Eckart Gottschalk et al. eds., 2007).

7 Gardella \& di Brozolo, supra note 1, at 623; ARTHUR T. VON MEHREN, AdJUDiCATORY Authority in Private InTERnational LaW: A COMParative Study 261-348 (2007); see Case C-185/07, Allianz SpA v. West Tankers Inc., 2009 E.C.R. I-00663.

8 See generally Jeffrey S. Parker \& Michael K. Block, Decision Making in the Absence of Successful Fact Finding: Theory and Experimental Evidence on Adversarial Versus Inquisitorial Systems of Adjudication, 24 InT'L REV. L. \& ECON. 89, 89-105 (2004); Amalia D. Kessler, Our Inquisitorial Tradition: Equity Procedure, Due Process, and the Search for an Alternative to the 
very little literature concerning conflicts between civil law and common law requirements for judgment recognition and enforcement (JRE) and grounds for refusing JRE. This paper intends to fill this gap by using the finality dispute between Mainland China and Hong Kong as an example.

Mainland China and Macao are influenced by the civil law tradition, ${ }^{10}$ whereas Hong Kong is governed by the common law tradition. ${ }^{11}$ In interregional JRE in China, conflicts between civil law and common law cause two problems: first, the same term may have different meanings in regional laws, and second, certain terms may exist in one regional law but not the other. The typical example is finality. The meaning of finality is significantly different between Mainland law and Hong Kong law, as well as Macao law and the two existing JRE Arrangements. ${ }^{12}$ Notably, the role that finality is supposed to play in

Adversarial, 90 CoRnell L. ReV. 1181 (2005); Francesco Parisi, Rent-Seeking Through Litigation: Adversarial and Inquisitorial Systems Compared, 22 INT’L REV. L. \& ECON. 193 (2002).

9 WENDY A. KENNETT, ENFORCEMENT OF JUDGMENTS IN EUROPE 63 (2000).

10 Zhenmin Wang, The Roman Law Tradition and Its Future Development in China, 1 FronTIERS L. CHINA 72, 72-78 (2006).

11 Hong Kong retains the common law tradition even after it was reunited with Mainland China. Article 8 of the Hong Kong Basic Law provides that "the laws previously in force in Hong Kong, that is, common law, rules of equity, ordinances, subordinate legislation and customary law shall be maintained, except for any that contravene this Law, and subject to any amendment by the legislature of Hong Kong." Article 84 further states that Hong Kong courts may refer to precedents of other common law jurisdictions when adjudicating cases but those precedents will only have reference value and no binding force over Hong Kong courts. For comments, see Albert H.Y. Chen, The Question of Conflict of Laws Between Mainland China and Hong Kong, in HUMAN Rights \& RULE OF LAW [Renquan Yu Fazhi] 48 n.43 (1987); see also Philip Smart, Enforcing Foreign Judgments After 1997, 4 H.K. LAw., Apr. 2002, at 144, available at http://www.hk-lawyer.com/InnerPages_features/0/835/2002/4.

12 The two existing JRE arrangements refer to the Arrangement on Reciprocal Recognition and Enforcement of Judgments in Civil and Commercial Matters by the Courts of the Mainland and of Hong Kong Pursuant to Choice of Court Agreements between the Parties Concerned, July 14, 2006 [hereinafter Mainland-Hong Kong Arrangement] and the Arrangement between the Mainland and Macao on the Mutual Recognition and Enforcement of Civil and Commercial Judgments [hereinafter Mainland-Macao Arrangement]. An English translation is available at Department of Justice (H.K.), Mainland related projects and legal issues, GovHK, http://www.doj.gov.hk/eng/topical/mainlandlaw.htm (last visited June 11, 2011). For Mainland China implementation legislation, see Zuigao Renmin Fayuan Guanyu Neidi Yu Xianggang Tebiexingzhengqu Fayuan Xianghu Renke He Zhixing Dangshiren Xieyi Guanxia De Minshangshi Anjian Panjue De Anpai [the Arrangement on Reciprocal Recognition and Enforcement of Judgments in Civil and Commercial Matters by the Courts of the Mainland and of Hong Kong Pursuant to Choice of Court Agreements between the Parties Concerned of the Supreme People's Court] (promulgated by the Supreme People's Court on Jul. 3, 2008, effective Aug. 1, 2008) (China). For Hong Kong implementation legislation, see Mainland Judgments (Reciprocal Enforcement) Ordinance and its (Commencement) Notice, No. 27, (2008) 12 O.H.K., $\S 195$. The Mainland-Macao Arrangement was signed by Mainland China and Macao on Feb. 28, 2006 and came into force on Apr. 1, 2006. In Mainland China, see Guanyu Neidi Yu Aomen Tebiexingzhengqu Guanyu Xianghu Renke He Zhixing Dangshiren Xieyi Guanxia De 
interregional JRE is also different in the U.S. and the EU. ${ }^{13}$ For example, finality is a requirement for JRE in the U.S. ${ }^{14}$ but it is not required by the Brussels I Regulation, ${ }^{15}$ although a requested court may stay the JRE proceedings if the judgment is challenged in the rendering region. ${ }^{16}$ Different meanings or different concepts of finality seem to concern only treaty interpretations and terminology choices. However, these different meanings reflect substantial conflicts between civil-law and commonlaw traditions.

Part I of this paper compares the criteria of "finality" under Mainland law and Hong Kong law. Part II explores the conflicts brought by the different criteria. It criticizes the Hong Kong precedent, Chiyu, by comparative studies with the U.S. and the EU law and by the statistics of retrials in Mainland China. It points out that strategic litigators have taken advantage of the Chiyu doctrine to conduct malicious re-litigations and forum shopping. It also presents the preferable minority approach adopted by Hong Kong courts. Part III proposes three possible solutions to solve the finality dispute: amend Hong Kong law, amend Mainland law, or adopt interregional law approaches. I conclude that Mainland China and Hong Kong should make compromises by amending their own laws or adopting an interregional law approach to solve the finality dispute.

\section{DIFFERENT CRITERIA OF "FINALITY" IN MAINLAND CHINA AND HONG KONG}

Finality is a requirement for JRE in Hong Kong: "[A] judgment shall be deemed to be final and conclusive notwithstanding that an appeal is pending against it, or that it may still be subject to appeal" in

Minshangshi Anjian Panjue De Anpai [the Arrangement between the Mainland and Macao on the Mutual Recognition and Enforcement of Civil and Commercial Judgments] (promulgated by the Supreme People's Court, Feb. 28, 2006, effective Apr. 1, 2006) (China).In Macao, see Announcement No 12/2006 of the Executive Chief of Macao on Mar. 14, 2006.

13 In this paper, interregional JRE is defined as recognizing and enforcing judgments between different regions within a country, such as between states in the United States and between Mainland China, Hong Kong and Macao in China, or within a supranational system, such as between member states in the EU. For details, see Jie Huang, Interregional Recognition and Enforcement of Civil and Commercial Judgments: Lessons for China from U.S. and EU Laws, 6 J. PRIVATE INT'L L. 109, 110-11 (2010).

14 For the finality criteria in the US law, see sources cited infra note 107.

15 Patrick Wautelet, Chapter III: Recognition and Enforcement (Art. 32), in BRUSSELS I Regulation 535, 540 (Ulrich Magnus \& Peter Mankowski eds., 2007).

16 Brussels I Regulation arts. 37, 46. 
the country where the judgment is rendered. ${ }^{17}$ Mainland JRE law does not use the term "finality" as a requirement for JRE. Instead, it requires that a judgment be legally effective [fa sheng fa lv xiao li de pan jue ]. ${ }^{18}$ Under Mainland law, "a legally effective judgment" refers to "a final judgment." ${ }^{\prime 19}$ Besides differences in terminology, the meaning of finality deviates significantly between Mainland China and Hong Kong. In brief, a final judgment should not be subject to any appeal but can be subject to retrial in Mainland China. ${ }^{20}$ However, Hong Kong courts hold that a judgment is final even if an appeal against it is pending, but a judgment is not final if it may be retried under the Mainland procedure for trial supervision. ${ }^{21}$ Therefore, a final Mainland judgment is never final under Hong Kong law, and vice versa.

\section{A. CRITERIA OF "FinAlity" UNDER MAINLAND LAW}

In Mainland China, a judgment becomes final when all appeals are exhausted ${ }^{22}$ or parties do not appeal with the time set by the statute of limitations. ${ }^{23}$ Judgments of the Supreme People's Court are final. ${ }^{24}$ In other words, unlike Hong Kong, Mainland courts hold that a judgment is not final if it is subject to appeal. Therefore, in the trial procedure, the finality standard under the Mainland law is stricter than that of the Hong Kong law.

Mainland China, unlike Hong Kong, has established a procedure for trial supervision to retry final judgments rendered in the trial procedure. ${ }^{25}$ The retrial can be conducted by the court rendering the

17 Foreign Judgments (Reciprocal Enforcement) Ordinance, (1997) Cap. 319, 1, § 3(3) (H.K.).

18 Zhonghua Renmin Gongheguo Renmin Fayuan Zuzhi Fa [The Organic Law of the People's Courts] (promulgated by the Nat'l People's Cong., July 1, 1979), arts. 11.3, 11.4, translated in http://www.lawinfochina.com (last visited June 14, 2011) [hereinafter Organic Law].

19 Art. 11.4 reads that "Zhongshen panjue he caiding, ye jiushi fasheng falv xiaoli de panjue he caiding" [a legally effective judgment is final]. It is suggested to refer to the Chinese version of this law, which makes its meaning clearer than the English version. Id. art. 11.4. Others disagree with my position. See Nanping Liu, A Vulnerable Justice: Finality of Civil Judgments in China, 13 Colum. J. Asian L. 35 (1999). In the context of discussing Mainland law, "final" refers to "legally effective" but the "final" in Mainland law is significantly different from that in Hong Kong law.

20 Organic Law, arts. 11, 13.

21 For details, see case cited infra note 29.

22 Organic Law, art. 11; see also Zhonghua Renmin Gongheguo Minshi Susong Fa [Civil Procedure Law of the People's Republic of China] (promulgated by the 4th Session of the 7th Nat'l People's Cong., effective Apr. 9, 1991, amended Oct. 28, 2007), art. 10, translated in http://www.lawinfochina.com (China) [hereinafter Mainland CPL]. Unless indicated otherwise, in this article "Mainland CPL" refers to the version amended in 2007.

${ }^{23}$ See Mainland CPL, supra note 22, arts. 147, 158.

24 Organic Law, art. 11.4.

${ }^{25}$ Mainland CPL, ch. 16 and Organic Law, art. 13 are about this procedure. 
original judgment, a court at the next higher level, or a court designated by the latter. ${ }^{26}$ If the court rendering the original judgment conducts the retrial, it should form a new collegial panel for the retrial. ${ }^{27}$ Notably, this procedure does not influence the finality and enforceability of a judgment unless a court with competent jurisdiction orders to stay the enforcement proceedings. ${ }^{28}$ This means that enforcement can go on even when a court or a prosecutor ("procuratorate") is reviewing the judgment but has not decided to commence the procedure for trial supervision. However, Hong Kong courts hold that all Mainland judgments are not final because of this procedure. ${ }^{29}$ In order to understand Hong Kong courts' holdings, it is necessary to discuss three important features of this procedure.

First, this procedure can be commenced by a party to a judgment or a procuratorate under circumstances provided by law. ${ }^{30} \mathrm{~A}$ procuratorate may lodge a protest on behalf of a party to a judgment, after it reviews and accepts this party's application. ${ }^{31}$ If a procuratorate lodges a protest against the judgment, a relevant people's court may retry the case ${ }^{32}$ but retrial does not necessarily lead to a reversal of the original judgment.

The second feature of the procedure for trial supervision is that a court can initiate a retrial sua sponte even without a party's motion when the judicial committee of a court discovers some definite error in a final judgment rendered by this court and deems it necessary to have the case retried..$^{33}$ If the Supreme People's Court or other people's court discovers some definite error in a final judgment of a people's court at a lower level, it can retry the case itself or direct a competent people's court to conduct a retrial. ${ }^{34}$

Third, if a party to a judgment would like to initiate a retrial, he or she must submit his or her application within two years after the original judgment becomes final. ${ }^{35}$ A party to a judgment can also apply for retrial, if within three months after he or she knows or should know

26 Mainland CPL, supra note 22, arts. 177, 181.

27 Id. art. 186.

28 Id. art. 185

29 E.g., Chiyu Banking Corp. Ltd. v. Chan Tin Kwun, [1996] 2 H.K.L.R. 395, 399 (H.C.).

30 Mainland CPL, supra note 22, arts. 179, 188.

31 Id. art. 188.

32 Id. art. 190.

33 Id. art. 177.

34 Id.

35 Id. art. 184. 
that the legal document on which the original judgment was made is cancelled or revised, or that the judge was involved in any conduct of embezzlement, bribery, practicing favoritism for himself or herself or relatives, or twisting the law in rendering judgment. ${ }^{36}$ There is no time limit for procuratorates to lodge a protest or a court to initiate a retrial sua sponte against a judgment. ${ }^{37}$

A key policy underlining the procedure for trial supervision is to ensure that parties have access to justice even if all appellate procedures have been exhausted and judgments have become final. ${ }^{38}$ In order to balance justice and finality of a judgment, Article 179 of the 2007 Civil Procedure Law (CPL) limits retrials to circumstances designated by law. ${ }^{39}$ This Article is based on Article 179 of the 1991 version. ${ }^{40}$ Both versions state that a people's court shall retry the case when a retrial application made by a party or when a procuratorate finds any of the listed circumstances. ${ }^{41}$ The old Article 179 is broader and less clear than the new version. For the convenience of comparison, the new Article 179 is divided into three categories.

The first category refers to the circumstances that are literally the same in both the new and old Article 179: (1) there is sufficient new evidence to set aside the prior judgment; ${ }^{42}(2)$ there was definite error in the application of the law in the prior judgment, ${ }^{43}$ and (3) the judge(s) who rendered the prior judgment committed embezzlement, accepted bribes, performed malpractice for personal benefits or perverted the law in the adjudication of the case.${ }^{44}$ However, the meaning of new evidence and the scope of erroneous application of law are undefined in the old Article 179. It is also unclear whether the case of judicial corruption

36 Id.

37 Id. arts. $177,187$.

38 Lu Song, The EOS Engineering Corporation Case and the Nemo Debet Bis Vexari Pro Una et Eadem Causa Principle in China, 7 CHINESE J. INT'L L. 143, 154 (2008) (“[T] he purpose of the trial supervision regime is not to defeat the finality and binding effect of a judgment, but to provide a judicial remedy in exceptional circumstances in which the decision is intolerably wrong."); see Donald C. Clarke, Power and Politics in the Chinese Court System: The Enforcement of Civil Judgments, 10 COLUM. J. ASIAN L. 1, 38-39 (1996).

39 Mainland CPL, supra note 22, art. 179.

40 Quanguo Renmin Daibiao Dahui Changwu Weiyuanhui Guanyu Xiugai Zhonghua Renming Gongheguo Mingshi Sushongfa de Jueding [Standing Comm. Nat'l People's Cong.'s Decision on the Amendment to the CPL] (promulgated by the Standing Comm. Nat'l People's Cong., Oct. 28, 2007, effective Apr. 1, 2008), art. 4 (China).

41 Mainland CPL, supra note 22, arts. 179, 187.

42 Id. art 179.1.

43 Id. art. 179.6.

44 Id. art 179. 
should be merged with the retrial. By contrast, in 2008 the Supreme People's Court issued a judicial interpretation, clarifying all these issues. ${ }^{45}$ Therefore, under the new Article 179, the courts will have clearer retrial standards to follow, so theoretically, less manipulation may occur.

Second, the 2007 CPL uses more concrete concepts to replace ambiguous wordings in the 1991 CPL. Examples include insufficient major evidence and undue process. ${ }^{46}$ Regarding the former, the old law only indicated that the major evidence by which the facts were established in the original judgment was insufficient. ${ }^{47}$ However, the meaning of "insufficient" is unclear. The new law does not use the abstract wording "insufficient"; instead, it states that (1) the major evidence by which the facts were established in the prior judgment was forged $;^{48}$ and (2) the major evidence by which the facts were established in the prior judgment has not been cross-examined. ${ }^{49}$ This clarification actually limits courts' discretion in making retrial decisions. ${ }^{50}$ As for undue process, the old law had an overbroad provision: a final judgment should be set aside if the judgment-rendering proceeding was unfair, which may have affected the correctness of the judgment in the case. ${ }^{51}$ The new law itemizes undue process as follows (1) the composition of the judicial panel was illegal or a judge(s) who should withdraw from the case has not; ${ }^{52}(2)$ any person with no legal capacity to engage in litigation did not have a guardian(s) as a legal representative(s) to act for him in a lawsuit, or a party who should participate in a lawsuit did not participate because of reasons beyond his or his legal representative's control; ${ }^{53}$ (3) a party's right to argue for himself or herself was deprived; $;{ }^{54}(4)$ a default judgment was made without summons $;{ }^{55}$ and (5)

45 Zuigao Renmin Fayuan Guanyu Shiyong Zhonghua Renmin Gongheguo Minshi Susongfa Shenpan Jiandu Chengxu Ruogan Wenti De Jieshi [Interpretation of the Supreme People's Court on Several Questions of Applying the Procedure for Trial Supervision under the Civil Procedure Law] (promulgated by the Supreme People's Court, Nov. 25, 2008, effective Dec. 1, 2008), arts. 10, 13, 18 (China). For the legal effects of judicial interpretation, see Daniel Vandekoolwyk, Threshold Obstacles to Justice: The Interaction of Procedural and Substantive Law in the United States, France, and China, 23 PaC. McGeorge Global Bus. \& DeV. L.J. 187 (2010).

46 Mainland CPL, supra note 22, arts. 179.2, 179.3, 179.4, 179.8, 179.9, 179.10.

47 Id. art. $179.2(1991)$.

48 Id. art. 179.3 .

49 Id. art. 179.4.

${ }^{50}$ For criticizing the concept of "major evidence," see infra note 67 and accompanying text.

51 Mainland CPL, supra note 22, art. 179.4.

${ }_{52}$ Id. art. 179.8 .

${ }_{53} \quad I d$. art. 179.9.

${ }^{54} I d$. art. 179.10. 
other unfair procedures. ${ }^{56}$ Therefore, compared with the old law, the new law is more concrete. Such development suggests that the value of finality should outweigh minor defects in procedure.

Third, compared with the old law, the new law adds new circumstances for retrial. Some new circumstances are reasonable; however, some are problematic. ${ }^{57}$

The reasonable new circumstances for retrial include: (1) the original trial court lacked jurisdiction; ${ }^{58}(2)$ an original judgment omitted or went beyond parties' claims; ${ }^{59}$ and (3) the legal document that original judgment or written order was based on has been cancelled or modified. ${ }^{60}$ The first and the third circumstances are certainly reasonable. The proportionality of the second circumstance deserves discussion. Retrial is costly not only for parties ${ }^{61}$ but also for the State. ${ }^{62}$ If a prior judgment omits parties' claims, then perhaps trying the omitted claim in new proceedings, rather than trying the whole case again, is a remedy proper enough for the parties. Similarly, invalidating the part of judgment that goes beyond parties' claims may be sufficient to relieve parties.

Insufficient basic evidence ${ }^{63}$ and the failure of a court in assisting parties to collect evidence ${ }^{64}$ are two of the problematic new circumstances. Under the new Article 179, a retrial can be commenced if the basic evidence was insufficient. ${ }^{65}$ The 2008 judicial interpretation states that basic evidence is about parties' identities, rights, obligations, and responsibilities, as well as the nature of the case, and it can substantially affect the results of a case ${ }^{66}$ Notably, besides insufficient basic evidence, forged or non cross-examined "major evidence" is also a ground for retrial under the new Article 179. ${ }^{67}$ However, no definition is provided for "major evidence." Therefore, it is unclear whether major

55 Id. art. 179.11.

${ }^{56}$ Id. art. 179.

57 Id. arts. 179.2, 179.3, 179.5, 179.7, 179.12, and 179.13 .

${ }_{58} \quad I d$. art. 179.7.

59 Id. art. 179.12.

${ }^{60} \quad I d$. art. 179.13.

${ }^{61}$ See Vandekoolwyk, supra note 45, at 211.

${ }^{62}$ Song, supra note 38 , at 145-46.

${ }_{63}$ Mainland CPL, supra note 22, art. 179.2.

${ }^{64} I d$. art. 179.5 .

${ }^{65} I$ Id. art. 179.2.

${ }^{66}$ Interpretation of the Supreme People's Court on Several Questions of Applying the Procedure for Trial Supervision under the Civil Procedure Law, supra note 45, art. 11.

67 Mainland CPL, supra note 22, art. 179.2-79.4. For comments on major evidence, see supra note 49 and accompanying text. 
evidence includes all evidence other than "basic evidence," or whether there exists minor evidence. It is also unclear how to determine the insufficiency of basic evidence. Without clarification, these ambiguities may lead to confusion in practice. A solution for this confusion is to combine provisions of basic and major evidence into one: any evidence that may affect the result of a case, that is forged, or that was not crossexamined should be a ground for retrial.

The other problematic new circumstance is Paragraph 1 Item 5 of the new Article 179. It states that a final judgment should be retried, if in the prior proceedings the judgment-rendering court did not help a party to collect evidence necessary to establish the basic facts of the case, and if for objective reasons this party was unable to collect this evidence and applied to the court in writing for help. ${ }^{68}$ It is unclear whether "the evidence necessary to establish the basic facts of the case" is the same as "basic evidence" or "major evidence." Moreover, "objective reasons" are undefined and no example is given. This paper argues that this article should be interpreted in line with Article 17 of the Supreme People's Court's Evidence Rule in Civil Litigation. ${ }^{69}$ This aims to make requirements for retrial stringent. It is also consistent with the Chinese legal reform that introduces party responsibility for collecting evidence. ${ }^{70}$ Moreover, the contents of "objective reasons" should be narrowly defined; otherwise, retrials may be abused.

Some scholars argue that the new CPL adds more circumstances for retrial because the number of grounds for retrial increases in the new

${ }^{68} I d$. art. 179.5 .

69 Article 17 of the Supreme People's Court's Evidence Rule in Civil Litigation indicates: In any of the following circumstances, the parties concerned and the agent $\mathrm{ad}$ litum thereof may plead the people's court to investigate upon and collect evidence:

1. The evidences applied for investigation and collection are the archive files kept by relevant organs of the state and must be accessed by the people's court upon authority;

2. The materials that concern state secrets, commercial secrets or personal privacy; or

3. Other materials that cannot be collected by the parties concerned or the agents ad litum thereof due to objective reasons.

Zuigao Renmin Fayuan Guanyu Minshi Susong Zhengju De Ruogan Guiding [the Supreme People's Court's Evidence Rule in Civil Litigation] (promulgated by the Supreme People's Court, Dec. 6, 2001, effective Apr. 1, 2002) (China), art. 17.

70 Margaret Y.K. Woo \& Yaxin Wang, Civil Justice in China: An Empirical Study of Courts in Three Provinces, 53 AM. J. CoMP. L. 911, 932 (2005); Nanning Zhang \& Douglas Walton, Recent Trends in Evidence Law in China and the New Evidence Scholarship, 9 L., PROBABILITY \& RISK 103, 112 (2010). 
Article $179 .^{71}$ However, broadening the grounds for retrial is not the same as loosening them. The earlier analysis demonstrates that the new law clarifies the old law in many aspects, ${ }^{72}$ which actually limits courts' discretion for retrial. ${ }^{73}$ Moreover, some of the newly added grounds for retrial are reasonable. ${ }^{74}$ However, it is undeniable that the concepts of "major evidence," "basic evidence," and "evidence necessary to establish the basic facts of the case" are confusing. Advisably, Mainland courts should restrictively interpret Article 179 and keep the requirements for retrials stringent.

\section{B. CRITERIA OF "FINALITY" UNDER HONG KONG JRE LAW: CHIYU AND ITS PROGENY}

The first case questioning the finality of a Mainland judgment was Chiyu Banking Corporation Limited v. Chan Tin Kwun. ${ }^{75}$ This case established that Hong Kong courts will not recognize or enforce a judgment rendered by a Mainland court that retains power to alter the judgment. ${ }^{76}$ It also implied that Hong Kong courts will recognize or enforce a judgment rendered by a Mainland court, even if a court higher than the judgment-rendering court maintains power to alter this

71 For arguments that retrials will happen more frequently in Mainland China because the number of grounds for retrial increases in the new CPL, see Xianchu Zhang, A New Stage of Regional Judicial Assistance in Civil and Commercial Matters: Implementation of the Mainland Judgments Ordinance and Certain Issues Beyond, 39 H.K.L.J. 3, 16 (2009); Mark Moedritzer, Kay C. Whittaker \& Ariel Ye, Judgments 'Made in China' But Enforceable in the United States?: Obtaining Recognition and Enforcement in the United States of Monetary Judgments Entered in China Against U.S. Companies Doing Business Abroad, 44 INT'L LAW. 817, 824 (2010).

72 See Mainland CPL, art. 179.1 (1991); Mainland CPL, supra note 22 art. 179.1.

73 See Mainland CPL, supra note 22, art. 179.3-79.4, 79.8-79.10; supra note 46 and accompanying text.

74 See supra note 58 and accompanying text.

75 Chiyu Banking Corp. Ltd. v. Chan Tin Kwun, [1996] 2 H.K.L.R. 395 (H.C.). In this case the plaintiff applied to a Hong Kong court for enforcing a Mainland judgment. This judgment was final under Mainland law, because all appellate procedures had been exhausted. The defendant applied to stay the Hong Kong proceedings on the grounds that he had requested a Mainland procuratorate to issue a protest against the judgment under the procedure for trial supervision. The defendant argued that if a protest would be lodged in due course, the judgment-rendering court would have to order a retrial and possibly the court would reverse the original judgment. The Hong Kong court concluded that the Mainland judgment was not final and conclusive for enforcement in Hong Kong in light of the procedure for trial supervision. For detailed analysis of this case, see Jie Huang, Overturning A Final Judgment Tainted By Fraud: A Comparison Between Mainland China and Hong Kong, 15 Willamette J. InT'L L. \& DisP. Resol. 47, 64 65 (2007).

76 Chiyu, [1996] 2 H.K.L.R. at 395. 
judgment. ${ }^{77}$ However, this case failed to answer an important question: will Hong Kong courts recognize and enforce the judgment if the people's procuratorate does not lodge a protest after reviewing the defendant's application? Or in other words, if the procuratorate does not lodge a protest, will the Mainland judgment become final? Professor Nanping Liu answers in the negative because under Mainland procedure for trial supervision, there is no time limit for a party to apply to a procuratorate to lodge a protest and the procuratorate has discretion in making its protest against a judgment at any time. ${ }^{78}$ Therefore, he argues that Mainland judgments will never become final and hence never become recognizable and enforceable in Hong Kong. ${ }^{79}$ This view has been adopted by Hong Kong courts in subsequent cases ${ }^{80}$ after Chiyu.

Chiyu and its progeny demonstrate that three elements exist in the Chiyu doctrine. First, Hong Kong law should be applied to determine whether a Mainland judgment is final and conclusive. ${ }^{81}$ Second, under Mainland law, a judgment will become final after being tried by two instances or after the period for appeal expires and no appeal is filed. ${ }^{82}$ However, importantly, under the Mainland procedure for trial supervision, a competent court-including the judgment-rendering court - can retry the case in limited circumstances provided by law. ${ }^{83}$ Therefore, however rare the circumstances may be, the judgmentrendering court may reverse its judgment in the retrial proceedings. The Chiyu court holds that if a court retains the power to reverse its own judgment, this judgment is not final ${ }^{84}$ Third, a mere likelihood of a retrial is sufficient to make a Mainland judgment unrecognizable and unenforceable in Hong Kong. ${ }^{85}$ For example, in Chiyu and Wuhan Zhong Shuo Hong Real Estate Co. Ltd. v. the Kwong Sang Hong Int'l. Ltd., the retrial proceedings obviously were not been triggered: the procuratorates had not decided to lodge a protest against the judgments, so the

77 Huang, supra note 75 , at 65.

78 Liu, supra note 19 , at 40,80 .

${ }^{79} I d$.

80 E.g., Wuhan Zhong Shuo Hong Real Estate Co. Ltd. v. Kwong Sang Hong Int'l. Ltd., [2000] 10 H.K.C. 711 (C.F.I.); Tan Tay Cuan v. Ng Chi Hung, [2001] 10 H.K.C. 164 (C.F.I.). For a detailed analysis of these two cases, see Huang, supra note 75, at 65-66.

81 Chiyu, [1996] 2 H.K.L.R. at 395.

82 Mainland CPL, supra note 22, art. 141.

83 Id. art. 179.

${ }^{84}$ Chiyu, [1996] 2 H.K.L.R. at 399.

85 E.g., Wuhan Zhong Shuo Hong Real Estate, [2000] 10 H.K.C. at 711; Cuan, [2001] 10 H.K.C. at 164. 
judgments were final and enforceable in Mainland China. ${ }^{86}$ Another example is Tan Tay Cuan v. Ng Chi Hung. ${ }^{87}$ In this case, the Supreme People's Court had not confirmed that it would retry the case, but the Hong Kong court still rejected JRE, holding that "it does not necessarily mean that it [retrial] will take place but certainly it may take place." 88

\section{CONFLICTS BROUGHT BY THE DIFFERENT CRITERIA OF FINALITY}

\section{A. Problems of Chiyu}

The Chiyu doctrine is problematic. First, it relies on the British precedent Nouvion v. Freeman, which held that a final judgment should not be revisited by the court that pronounced it and, in situations where the judgment is erroneous, a higher court should have jurisdiction to reopen the case.$^{89}$ However, the Chiyu doctrine interprets this precedent without looking into the specific facts of Nouvion.

Nouvion involves a Spanish remate judgment obtained in executive proceedings. ${ }^{90}$ Under Spanish law, there are two types of proceedings. One is an executive or summary proceeding and the other is an ordinary, plenary, or declarative proceeding. ${ }^{91}$ Both proceedings can be brought against the same subject-matter and between the same parties. ${ }^{92}$ However, the judgment obtained in executive proceedings, the so-called remate judgment, has no res judicata effect. ${ }^{93}$ In other words, "the rights of the parties with reference to the original cause of action are in no way affected by any judgment obtained in the executive proceedings" $"$ and the remate judgment "merely ... give[s] a right to the plaintiff in the action to get execution on the assumption that he has got a good cause of action by the document on which he sues." 95 Furthermore, the remate judgment is not a decision that exhausts the merits of the

86 E.g., Wuhan Zhong Shuo Hong Real Estate, [2000] 10 H.K.C. at 711.

${ }^{87}$ Cuan, [2001] 10 H.K.C. at 164.

88 Id. (emphasis added).

89 See Nouvion v. Freeman, [1889] 15 App. Cas. 1 (Eng.).

${ }^{90}$ See id.

91 Nouvion v. Freeman, [1887] 37 Ch.D. 244 (Eng.), aff'd, [1889] 15 App. Cas. 1. The executive proceedings are theoretically cheaper and faster than ordinary proceedings. Francisco Ramos Méndez, Provisional Remedies IN SPANish Civil Procedure 2, available at http://www.rya.es/articulos/Provisional_\%20Remedies_in_Spanish_Civil_Procedure.pdf. (last visited June 23, 2011).

92 Nouvion, [1887] 37 Ch.D. at 244.

93 Id.

94 Id.

95 Id. 
controversy between the parties, because in executive proceedings, the defendant can only makes certain pleas of a certain prescribed and definite character. ${ }^{96}$ The same court that rendered the remate judgment can also hear an ordinary or plenary action to decide every plea that the defendant may raise, including those that had been decided in the previous executive proceedings. ${ }^{97}$

For two reasons the Spanish remate judgment is fundamentally distinct from a final Mainland judgment obtained in the trial procedure. First, the Mainland judgment conclusively decides the rights of the parties and has res judicata effect between them. ${ }^{98}$ Second, a defendant can raise all pleas against a plaintiff's claims in the Mainland trial procedure. Moreover, if a judgment is obtained through trial procedure, a party can apply to retry only in very limited grounds, such as discovering important new evidence or corrupt judges. ${ }^{99}$ Therefore, the Nouvion holding should not be applied to Mainland judgments.

Moreover, Nouvion does not establish a general rule. English case law in the nineteenth century (when Nouvion was rendered) also "established that a foreign judgment could be enforced in England despite the fact that there was a possibility that the foreign court might have to revisit its original decision." 100

The second problem of Chiyu is that it improperly applies the law of the requested court to determine the finality of a judgment in the JRE proceedings. It ignores the fact that a Mainland judgment is enforceable in Mainland China even if an application for retrial has been submitted to a court or a procuratorate. ${ }^{101} \mathrm{~A}$ mere likelihood of retrial cannot make the judgment unenforceable in Mainland China. ${ }^{102}$ Therefore, the Mainland judgment should be recognizable and enforceable in other regions unless other grounds for refusal exist.

By way of comparison, in the United States, generally the law of the region where the judgment was rendered determines its finality. ${ }^{103}$ Although the Full Faith and Credit Clause of the U.S. Constitution does

96 Nouvion, [1889] 15 App. Cas. at 1.

${ }^{97} I d$.

98 Mainland CPL, supra note 22, art. 141.

99 See id. art. 179.

${ }^{100}$ Philip Smart, Enforcement of Foreign Judgments, in ENFORCING JudgMENTS IN HONG Kong 255, 267 (Christine N. Booth ed. 2004); Vanquelin v. Bouard, (1863) 15 C.B. (N.S.) 341 (Eng.).

${ }^{101}$ Mainland CPL, supra note 22, art. 185.

${ }^{102}$ See id.

${ }^{103}$ Clermont, supra note 6, at 98. 
not explicitly require finality as a precondition for JRE, ${ }^{104}$ in practice, except in child support and similar cases ${ }^{105}$ only final judgments can be recognized and enforced in sister states. ${ }^{106}$ The leading practice is that a requested court should determine finality according to the law of the judgment-rendering region. ${ }^{107}$ The Judiciary Act of 1790 explained the Full Faith and Credit Clause: "Such Acts, records and judicial proceedings or copies thereof, so authenticated, shall have the same Full Faith and Credit in every court. . a as they have by law or usage in the courts of such State ... from which they are taken." 108 This statement clearly indicates that the issues of finality and conclusiveness should be determined by "the law and usage" of the judgment-rendering state. ${ }^{109}$ The second Restatement of Conflict of Laws also provides the same rule. ${ }^{110}$ For example, Paine v. Schenectady Insurance Co. involved conflicting judgments from Rhode Island and New York with appeals pending against both. ${ }^{111}$ An enforcement proceeding of New York judgment was brought in a Rhode Island court. ${ }^{12}$ The court held that the law of the judgment-rendering region should decide the effect of appeal, retrial and the like on the finality of a judgment. ${ }^{113}$ Although under the Rhode Island law an appeal would vacate a judgment, under New York law, it did not. ${ }^{114}$ Therefore, the court consequently enforced the New York judgment. ${ }^{115}$ Moreover, in 2008 a U.S. court recognized and enforced a Mainland judgment. ${ }^{116}$ Although this judgment is subject to the procedure of trial supervision, the U.S. court held that it "was final,

${ }^{104}$ See Vardon Golf Co. v. Karsten Mfg. Corp., 294 F.3d 1330, 1334 (Fed. Cir. 2002); Pure Distributors Inc. v. Baker, 285 F.3d 150, 157 (1st Cir. 2002); Barber v. Barber, 323 U.S. 77, 87 (Jackson, J., concurring).

${ }^{105}$ See The Full Faith and Credit for Child Support Orders Act, 28 U.S.C. § 1738B (1994).

${ }^{106}$ Pure Distributors, 285 F.3d at 157; Note, The Finality of Judgments in the Conflict of Laws, 41 COLUM. L. REV., 878, 878 (1941).

${ }^{107}$ Clermont, supra note 6, at 98.

${ }^{108} 28$ U.S.C. $\S 1738$ (1964) (originally enacted in 1790) (emphasis added); EUGENE F. SCOLES ET AL., CONFLICT OF LAWS 1262 (4th ed. 2004).

109 Scoles et AL., supra note 108, at 1262; SymeOn C. Symeonides, American Private INTERNATIONAL LAW 330 (2008).

110 Restatement (SECOND) OF CONFLict OF LAWs $\S 95 \mathrm{cmt}$. g (1971).

${ }^{111}$ Paine v. Schenectady Ins. Co., 11 R.I. 411, 412 (R.I. Sup. Ct. 1876).

${ }^{112} I d$.

${ }^{113}$ Id. at 416 (citing Bank of North America v. Wheeler, 28 Conn. 433, 441-43 (Conn. Sup. Ct. 1859)).

${ }^{114} I d$. at 416.

${ }^{115} \mathrm{Id}$.

${ }^{116}$ Hubei Gezhouba Sanlian Indus. Co. v. Robinson Helicopter Co., No. 2:06-cv-01798-FMC-SS-x 2009 WL 2190187, at*7 (C.D. Cal. July 22, 2009). For comments on this case, see Moedritzer, Whittaker \& Ye, supra note 71 , at $825,833$. 
conclusive, and enforceable under the laws of the PRC," 117 because "the UFMJRA, adopted in California and codified . . . applies to any foreign judgment that is final, conclusive, and enforceable under the laws where rendered." 118

Under the Brussels I Regulation, finality is not a requirement for JRE. ${ }^{119}$ However, the requested court may stay recognition proceedings upon the application of the judgment debtor, who lodges an appeal against the judgment in the judgment-rendering region. ${ }^{120}$ Nevertheless, "[t]he mere lodging of a complaint with the authorities," ${ }^{121}$ like the judgment debtor did in Chiyu and its progeny, "against parties who are involved in the proceedings in the country of origin, does not as such constitute an ordinary appeal." 122 Article 46 of the Regulation empowers requested courts to stay enforcement proceedings when the time for appeal has not yet expired, even if the judgment debtor has not lodged an appeal. ${ }^{123}$ This approach looks like that adopted by the progeny of Chiyu, which held that Mainland judgments were never final because the procuratorates' right to protest had no time limit. ${ }^{124}$ However, notably, Article 46 of the Brussels I Regulation particularly aims to counterbalance the unilateral nature of the enforcement proceedings laid down by Article 38 et seq. ${ }^{125}$ Those Articles extend enforceability of a judgment from the judgment-rendering state to the requested state immediately on completion of the formalities requirement and without reviewing grounds to defend the enforcement. ${ }^{126}$ However, there is no equivalent Article in the Chinese contexts. Therefore, the needs of such counterbalance do not exist in the contexts of Chinese interregional JRE. Therefore, Chiyu and its progeny improperly apply the law of the

\footnotetext{
${ }^{117}$ Hubei Gezhouba Sanlian Indus. Co., No. 2:06-cv-01798-FMC-SS-x 2009 WL 2190187, at *7.

${ }^{118} I d$. at *5 (emphasis added).

${ }^{119}$ Article 37 of the Brussels I Regulation (Council Regulation 44/2001, art. 37, 2000 O.J. (L 12) 10 (EC)).

${ }^{120} \mathrm{Id}$.

${ }^{121}$ Wautelet, supra note 15.

${ }^{122} I d$.

${ }^{123}$ Brussels I Regulation, art. 46; see Wautelet, supra note 15, at 629 (discussing of the differences between articles 37 and 46 ).

${ }^{124}$ Chiyu Banking Corp. Ltd. v. Chan Tin Kwun, [1996] 2 H.K.L.R. 395 (H.C.); see Liu, supra note 19 , at 40 .

${ }^{125}$ Lennart Palsson, Chapter III: Recognition and Enforcement (Art. 46), in BRUSSELS I REgUlation 670 (Ulrich Magnus \& Peter Mankowski eds., 2007).

${ }^{126}$ Brussels I Regulation, arts. 38, 41, available at http://curia.europa.eu/common/recdoc/ convention/en/c-textes/02001R0044.pdf. For comments, see Konstantinos Kerameus, Chapter III: Recognition and Enforcement (Art. 41), in BRUSSELS I REgUlation 645, 654 (Ulrich Magnus \& Peter Mankowski eds., 2007).
} 
requested court to determine the finality of the judgment and ignore its enforceability in Mainland China.

Third, Chiyu causes Hong Kong courts to recognize and enforce Mainland judgments differently from how it treats judgments from other jurisdictions, such as the U.S.. For example, Hong Kong courts refuse to recognize and enforce Mainland judgments because the judgmentrendering court has the power to retry the case. ${ }^{127}$ In the U.S., under the Federal Rules of Civil Procedure (FRCP) 59 and 60, the district court that renders a judgment also retains the power to revise the judgment on its own motion. ${ }^{128}$ However, Hong Kong courts do not hold that U.S. judgments rendered by district courts are unrecognizable and unenforceable because the judgment-rendering courts maintain the power to retry the case. ${ }^{129}$

For example, a default judgment rendered by a U.S. district court may be set aside by the court that pronounced it. ${ }^{130}$ Nonetheless, such a judgment is recognizable and enforceable in Hong Kong. ${ }^{131}$ In Nintendo of America Inc. v. Bung Enterprises Ltd., the plaintiff applied to enforce a default judgment rendered by the Western Division of the U.S. District Court of the Central District of California. ${ }^{132}$ The defendant made a meritorious defense at the beginning of the U.S. proceedings but later defaulted. ${ }^{133}$ In the Hong Kong JRE proceedings, the defendant argued that the U.S. judgment was not final and conclusive because it could be set aside by the judgment-rendering court upon a reconsideration motion. ${ }^{134}$ Similarly to the defendant in Chiyu, the defendant in this case also relied on Gustave Nouvion and argued that the American judgment was like the Spanish judgment that "might be at any time recalled or modified" by the judgment-rendering court. ${ }^{135}$ The Hong Kong Court of First Instance distinguished the Spanish judgment in Nouvion from the American judgment because the former "was known as a . . remate ... judgment[,] which was a judgment after consideration of limited issues and which was liable to be reconsidered in ... plenary ... proceedings

\footnotetext{
${ }^{127}$ Chiyu, [1996] 2 H.K.L.R. at 395.

${ }^{128}$ FED. R. CIV. P. 59(d), 60(a).

${ }^{129}$ See, e.g., Nintendo of America Inc. v. Bung Enterprises Ltd., [2000] HCA 1189/2000 (H.C.A. Mar. 21, 2000) (H.K.), available at http://legalref.judiciary.gov.hk/lrs/common/ search/search_result_detail_frame.jsp?DIS $=21867 \& Q \mathrm{QS}=\% 2 \mathrm{~B} \& \mathrm{TP}=\mathrm{JU}$.

${ }^{130}$ FED. R. CIV. P. 55(c), 60(b).

${ }^{131}$ Nintendo, [2000] HCA 1189/2000 @ 10

${ }_{132}$ Id. $₫ 3$.

${ }_{133} I d$ ๆ 1.

${ }^{134} \mathrm{Id}$.

${ }^{135}$ Id. $\uparrow 8$.
} 
where the whole merits of the matters might be gone into." ${ }^{136}$ The court held that the U.S. judgment should be enforced regardless of whether the judgment-rendering court retains the power to set it aside. ${ }^{137}$ It first relied on a famous treatise by Dicey and Morris:

$[\mathrm{I}] \mathrm{t}$ is well established that for the purpose of enforcement by an action in Hong Kong, a foreign judgment may be final and conclusive even though it is a default judgment liable to be set aside in the very Court which rendered it. ${ }^{138}$

The Hong Kong court analogized the case to Vanquelin $v$. Bouard and accepted the Vanquelin holding. ${ }^{139}$ In Vanquelin, a judgment creditor attempted to enforce a French default judgment in the United Kingdom, and the judgment debtor argued that the enforcement should be refused because if it appeared in the French court, the French judgment-rendering court may revise the judgment. ${ }^{140}$ Chief Judge Erle in Vanquelin rejected this argument because a mere possibility of retrial in the judgment-rendering court is insufficient to deny JRE in Hong Kong:

I apprehend that every judgment of a foreign court of competent jurisdiction is valid and may be the foundation of an action in our courts, though subject to the contingency, that, by adopting a certain course, the party against whom the judgment is obtained might cause it to be vacated or set aside.

But until that course has been pursued, the judgment remains in full force and capable of being sued upon. ${ }^{141}$

The defendant also argued that he had instructed his U.S. attorney to seek the U.S. judgment-rendering court's reconsideration of the default judgment and planned to appeal if the reconsideration motion failed. ${ }^{142}$ This argument is essentially identical to the defendant's argument in Chiyu - he had requested a Mainland procuratorate to issue a protest against the judgment under the procedure for trial supervision. ${ }^{143}$

136 Id.

137 Id. ๆ 10-12.

138 DiCEY AND MORRIS ON THE CONFLICT OF LAWS 477 (13th ed. 2000) (emphasis added).

139 Vanquelin v. Bouard, (1863) 15 C.B. (N.S.) 341 (Eng.).

${ }^{140} \mathrm{Id}$.

${ }^{141} I d$. at 367-68 (emphasis added).

${ }^{142}$ Under Rule 60 of the U.S. FRCP, parties to a final judgment can obtain relief from this judgment by filing a motion for relief within a reasonable time. FED. R. CIV. P. 55(c).

143 Chiyu Banking Corp. Ltd. v. Chan Tin Kwun, [1996] 2 H.K.L.R. 395 (H.C.). In Chiyu, the defendant requested the Fujian People's Procuratorate to lodge a protest against the final judgment. The Fujian Procuratorate referred this matter to the Supreme People's Procuratorate, 
However, in contrast to Chiyu, the Nintendo of America Inc. court rejected this argument and held that although the defendant had given instructions to his attorney, the U.S. court had not begun to take any step in reversing the judgment, so the judgment was deemed final in Hong Kong. ${ }^{144}$

Many other important similarities exist between Chiyu and Nintendo of America Inc. First, both judgment-rendering courts retained the power to revise the judgment under their retrial procedure. Second, both defendants invoked Gustave Nouvion. Third, both defendants took some steps to initiate the retrial procedure. In Chiyu, the defendant applied to a people's procuratorate, and in Nintendo of America Inc. the defendant instructed its attorney to submit a reconsideration motion to the American court. In both cases, neither of the judgment-rendering courts decided to retry the case. However, regardless of these significant similarities, Hong Kong courts refused the recognition and enforcement of the Mainland judgment in Chiyu but recognized and enforced the American judgment in Nintendo of America Inc. Hong Kong courts have not yet justified the different treatments between Mainland judgments and those from other jurisdictions.

\section{B. REASONS FOR CHIYU}

Unfamiliarity with and distrust of the Mainland procedure for trial supervision may explain why, despite the similar facts of Chiyu and Nintendo of America Inc., Hong Kong courts decided them differently. Arguably, the requested Hong Kong courts improperly ignore the following four aspects.

First, not every application submitted by parties can convince a Mainland procuratorate to lodge a protest against a judgment. ${ }^{145}$ It is unfair to leave a judgment in the hands of a losing party who tries to delay the enforcement by applying for retrials without a legitimate reason. The late Hong Kong Professor Philip Smart correctly pointed out that Chiyu overly favors a defendant who has no claims such as fraud, undue process, and public policy exception, and can defeat the enforcement of a

but the latter had not made a decision yet. Based on this fact, the defendant argued that "if a protest is in due course lodged, the Intermediate Court will have to order a retrial with the possibility of the court reaching a different result on the case." Id. at 397.

${ }^{144}$ Nintendo of Am. Inc. v. Bung Enter. Ltd., [2000] HCA 1189/2000, $₫ 10$ (H.C.A. Mar. 21, 2000) (H.K.).

${ }^{145}$ Renmin Jianchayuan Minshi Xingzheng Kangsu Anjian Banan Guize [Regulation of People's Procuratorate Handling Civil and Administrative Protest Case] (promulgated by Supreme People's Prosecutorate, Sep. 30, 2001, effective Sep. 30, 2001), art. 26 (China). 
judgment in Hong Kong by merely submitting a retrial application to a Mainland procuratorate. ${ }^{146}$

Second, under Mainland law, even if a procuratorate lodges a protest against a judgment, the judgment is still final and enforceable in Mainland China until a court with competent jurisdiction orders to stay the enforcement. ${ }^{147}$ Although Hong Kong courts apply Hong Kong law in its enforcement proceeding, the law of the judgment-rendering court regarding finality should be taken into account. Therefore, it is unreasonable to deny recognition and enforcement of a Mainland judgment for lack of finality, when this judgment is final and enforceable in the region where it is rendered. ${ }^{148}$

Third, according to Hong Kong Foreign Judgment (Reciprocal Enforcement) Ordinance (FJREO) judgments are enforceable although an appeal is possible or even pending ${ }^{149}$ it is justifiable to do the same with a judgment subject to retrial. Retrial in Mainland China is similar to appeal in three important aspects: (1) Both of them aim to ensure the losing party's access to justice. Retrial follows the appellate procedure, except when the retried judgment was rendered by a first-instance court (in this case, the first-instance procedure applies). ${ }^{150}$ (2) Both review facts and laws decided by the original judgment. ${ }^{151}$ (3) The commencement of retrial or appeal does not automatically lead to reversal of the original judgment. ${ }^{152}$

Fourth, in practice only very few cases are retried in Mainland China. In 2002, the Supreme People's Court issued a judicial interpretation to restrict parties or courts to one retrial in each case. ${ }^{153}$ The 2007 Mainland CPL, compared the 1991 version that the Chiyu court considered, clarifies the grounds for retrial in many aspects. ${ }^{154}$ Thus courts have less discretion in reopening a final judgment. Moreover, according to statistics, only a small percentage of cases have been retried

\footnotetext{
${ }^{146}$ Smart, supra note 100 , at 268.

${ }^{147}$ Mainland CPL, supra note 22, art. 185; Clarke, supra note 38, at 39.

${ }^{148}$ See supra note 89 and accompanying text.

${ }^{149}$ Foreign Judgments (Reciprocal Enforcement) Ordinance, (1997) Cap. 319, 1, § 3(3) (H.K.), available at http://www.hklii.org/hk/legis/en/ord/319/s3.html.

${ }^{150}$ Mainland CPL, supra note 22, art. 186.

${ }^{151}$ Id. art. 151.

152 Mainland CPL, supra note 22, art. 153.

153 Zuigao Renmin Fayuan Guanyu Renmin Fayuan Dui Minshi Anjian Fahui Chongshen He Zhiling Zaishen Youguan Wenti De Guiding [Provisions of the Supreme People's Court on the Relevant Issues of Remanding for a New Trial and Ordering for a Retrial of Civil Case] (promulgated by the Judicial Comm. of the Supreme People's Ct., Apr. 15, 2002, effective Aug. 15, 2002, arts. 2-3 (China).

${ }^{154}$ See supra note 42 and accompanying text.
} 
since the Mainland Supreme People's Court and Supreme People's Procurator adopted the policy of restricting retrials and of respecting the finality of judgments in 2001. ${ }^{155}$

Charts I, II, and III below show that, generally, in one thousand final civil judgments rendered in the trial and appellate procedures: (1) fewer than ten judgments $(10 / 1000)$ were reopened in the procedure for trial supervision; and (2) about four judgments (4/1000) were found erroneous in the procedure for trial supervision.

\section{Chart I ${ }^{156}$}

\begin{tabular}{|c|c|c|c|}
\hline Year & $\begin{array}{c}\text { Number of } \\
\text { Civil Cases } \\
\text { Accepted for } \\
\text { Trial }\end{array}$ & $\begin{array}{c}\text { Number of Civil } \\
\text { Cases Accepted } \\
\text { for Retrial }\end{array}$ & $\begin{array}{c}\text { The Percentage of } \\
\text { Retried Cases } \\
\text { among the Total } \\
\text { Civil Cases (\%) }\end{array}$ \\
\hline 1999 & $5,480,178$ & 83,915 & 1.53 \\
\hline 2000 & $5,153,374$ & 83,201 & 1.61 \\
\hline 2001 & $5,074,080$ & 82,652 & 1.63 \\
\hline 2002 & $4,830,000$ & 48,180 & 0.997 \\
\hline
\end{tabular}

155 The policy is embodied in the following regulations: e.g., Zuigao Renmin Jianchayuan Minshi Xingzheng Jianchating Guanyu Guifan Shengji Renmin Jianchayuan Banli Minshi Xingzheng Tiqing Kangsu Anjian De Yijian [Opinion to Regulate Protests by the People's Procurator at the Provincial Level] (promulgated by the Supreme People's Procurator, Aug. 14, 2001) (China); People's Procurator Rule of Making Protests in Civil and Administrative Cases, supra note 145; Zuigao Renmin Fayuan Guanyu Yinfa Quanguo Shenpan Jiandu Gongzuo Zuotanhui Guanyu Dangqian Shenpan Jiandu Gongzuo Ruogan Wenti De Jiyao [Notice of Several Questions concerning the Procedure for Trial Supervision made by the Supreme People's Court] (promulgated by the Supreme People's Ct., Nov. 1, 2001) (China); Provisions of Remanding for a New Trial and Ordering for Retrial of Civil Case, supra note 153; and see Li You Rong v. Li Rui Qiong, CACV 159/2004, थ 16, available at http://legalref.judiciary.gov.hk//rs/common/search/search_result_detail_frame.jsp?DIS= 50881\&QS=\%2B\&TP=JU (last visited Aug. 13, 2011).

156 Jingwen Zhu, Zhong Guo Fa Lv Fa Zhan BaO GaO: Shu Ju Ku He Zhi Biao Ti Xi [Report ON CHINESE LAW DEVELOPMENT: DATABASE AND INDICATORS] 205, 240 (2007).

157 The number of closed civil cases before 2003 was not found by the author when compiling this paper. 


\section{Chart II ${ }^{158}$}

\begin{tabular}{|c|c|c|c|}
\hline Year & $\begin{array}{c}\text { Number of Closed Civil } \\
\text { Cases }\end{array}$ & $\begin{array}{c}\text { Number of } \\
\text { Civil Cases } \\
\text { Accepted for } \\
\text { Retrial }\end{array}$ & $\begin{array}{c}\text { The Percentage of } \\
\text { Retried Cases } \\
\text { among the Closed } \\
\text { Civil Cases (\%) }\end{array}$ \\
\hline 2003 & $4,416,168$ & 46,151 & 1.05 \\
\hline 2004 & $4,303,744$ & 45,205 & 1.05 \\
\hline 2005 & $4,360,184$ & 41,461 & 0.95 \\
\hline 2006 & $4,382,407$ & 43,140 & 0.98 \\
\hline 2007 & $4,682,737$ & 37,766 & 0.81 \\
\hline 2008 & $5,381,185$ & 35,246 & 0.65 \\
\hline 2009 & $5,797,160$ & 37,429 & 0.65 \\
\hline 2010 & $6,112,695$ & 40,906 & 0.67 \\
\hline
\end{tabular}

Charts I and II demonstrates that less than 1 percent of final judgments were reopened each year since 2005 under the procedure for trial supervision. After 2002, the number of civil cases accepted for retrial keeps decreasing because people's courts adopted the policy of restricting retrials and of respecting the finality of judgments. ${ }^{159}$

\section{Chart III ${ }^{160}$}

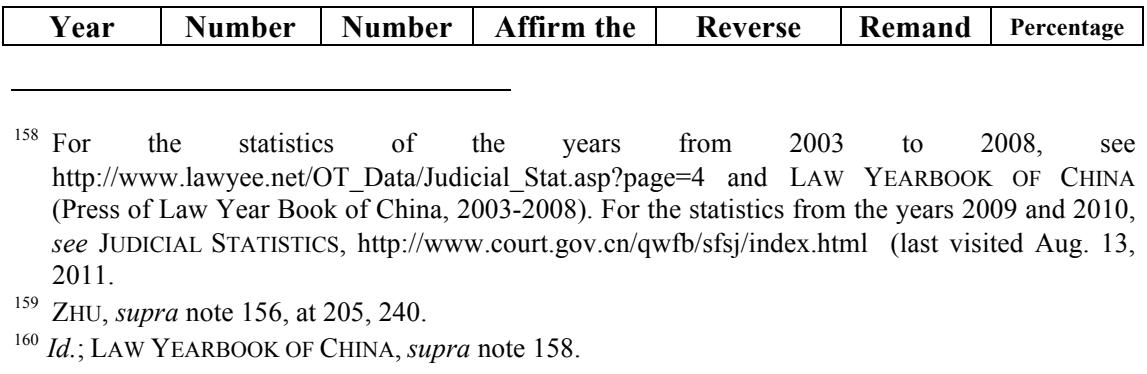




\begin{tabular}{|c|c|c|c|c|c|c|}
\hline & $\begin{array}{c}\text { of Civil } \\
\text { Cases } \\
\text { Accepted } \\
\text { for } \\
\text { Retrial }\end{array}$ & $\begin{array}{c}\text { of Civil } \\
\text { Cases } \\
\text { Finished } \\
\text { Retrial }\end{array}$ & $\begin{array}{c}\text { Original } \\
\text { Judgments }\end{array}$ & $\begin{array}{c}\text { the } \\
\text { Original } \\
\text { Judgments }\end{array}$ & $\begin{array}{c}\text { the } \\
\text { Cases }\end{array}$ & $\begin{array}{c}\text { of } \\
\text { Reversed } \\
\text { \& } \\
\text { Remanded } \\
\text { Cases } \\
\text { among } \\
\text { Cases } \\
\text { That } \\
\text { Finished } \\
\text { Retrial* }\end{array}$ \\
\hline 1999 & 83,915 & 81,949 & 17,591 & 18,898 & 4,830 & 28.95 \\
\hline 2000 & 83,201 & 85,155 & 20,294 & 21,276 & 5,081 & 30.95 \\
\hline 2001 & 82,652 & 82,550 & 21,721 & 21,050 & 4,683 & 31.17 \\
\hline 2002 & 48,180 & 48,916 & 16,514 & 15,290 & 2,575 & 36.52 \\
\hline 2003 & 46,151 & 47,412 & 15,742 & 15,167 & 2,644 & 37.57 \\
\hline 2004 & 45,250 & 44,211 & 13,709 & 15,161 & 3,014 & 41.11 \\
\hline 2005 & 42,737 & 41,461 & 13,484 & 13,965 & 3,044 & 41.02 \\
\hline 2006 & 43,140 & 42,255 & 14,376 & 13,758 & 2,998 & 39.65 \\
\hline 2007 & 37,766 & 38,786 & 13,414 & 11,569 & 2,849 & 37.17 \\
\hline 2008 & 35,246 & 35,704 & 11,719 & 10,492 & 3,107 & 38.09 \\
\hline 2009 & 37,429 & 38,070 & 11,649 & 10,106 & 4,325 & 37.91 \\
\hline 2010 & 40,906 & 41,331 & 11,683 & 9,953 & 5,012 & 36.19 \\
\hline
\end{tabular}

*The percentage of erroneous final judgments rendered in the trial and appellate procedures

Chart III demonstrates that after 2002, the number of cases accepted for retrial decreased. Meanwhile, the percentage of cases remanded and reversed under the retrial procedure increased. This contrast implies that the decline of the former resulted from the policy of restricting retrials and of respecting the finality of judgments. ${ }^{161}$ In other words, the fact that fewer cases are accepted for retrial does not necessarily represent an improvement of the quality of civil judgments in the trial and appellate procedures. Moreover, compared with 2009, although the number of cases accepted for retrial increased in 2010, the percentage of reversed and remanded cases among cases that finished retrial did not increase. This shows that courts consistently follow the policy of restricting retrials.

${ }^{161}$ ZHU, supra note 156, at 205, 240. This report also shows that: 1) from 1978-1987, the number of cases accepted for retrial and the number of remanded and reversed cases both increased, which means that the quality of civil judgments declined; 2) from 1992-2001, the number of cases accepted for retrial greatly increased and remained at a high level. Meanwhile, the percentage of cases remanded or reversed in the retrial procedure also greatly increased. This means the quality of civil judgments declined again. Id. 
Moreover, if the retrial court holds that an originally final judgment is erroneous, it may reverse the judgment, ${ }^{162}$ or remand the case to the court that rendered the original judgment or to another lower court for a new trial. ${ }^{163}$ Chart III shows that about four out of one thousand final judgments rendered in the trial and appellate procedures are reversed as erroneous. The finding (0.004) is from this formula:

$$
1 \text { percent }(\text { Chart I }) * 40 \text { percent }(\text { Chart II })=0.004 \text {. }
$$

Two factors may affect this finding. First, remanding a case does not mean the previous judgment was erroneous and would be reversed in retrial. Therefore, the actual erroneous rate should be lower than 0.004. Second, it is unknown what happened to cases in the category of "others." 164 Therefore, it is hard to assess how the "others" affects the erroneous rate.

In Chart III, the numbers for affirmed, reversed, and remanded don't add up to the number of cases where retrial was completed. The rest of cases fall into one of the following categories:

1. The original final judgment is affirmed. Chart III shows that the number of final judgments that were affirmed in the retrial was close to the number of final judgments reversed in the retrial.

2. The retrial is dismissed. This happens when the circumstances for retrial are not satisfied under the Chapter 16 of the Mainland CPL.

3. The party applying for retrial withdraws the request.

4. Parties reach a settlement.

5. Others. A fairly large number of retried cases are in this category, but the statistics do not clarify the meaning of "others." 165

Notably, dismissing and withdrawing retrials won't vacate the previous judgments. Settlements are parties' voluntary actions. ${ }^{166}$ Settlements are unlike new judgments resulting from courts' reversal of previous judgments. Although settlement may result in revising the previous judgments, it also does not affect the finality of the previous

162 Interpretation of the Supreme People's Court on Several Questions of Applying the Procedure for Trial Supervision under the Civil Procedure Law, supra note 45, art. 39.

163 Id. arts. 27. For circumstances where the court that rendered the original judgment cannot retry the case, see $i d$. art. 29.

164 ZHU, supra note 156, at 205, 240.

165 The number of cases in this category each year is: 20,609 in the year of $1999 ; 20,360$ in 2000; 18,973 in $2001 ; 10,113$ in $2002 ; 9,508$ in $2003 ; 7,916$ in $2004 ; 6,453$ in $2005 ; 6,059$ in 2006; 5,369 in 2007; 5,322 in 2008; 6,040 in 2009; and 7,038 in 2010. JUDICIAL STATISTICS, supra note 158 .

${ }^{166}$ Mainland CPL, supra note 22, art. 51. 
judgments. For example, parties often reach settlements in executing judgments, which is equivalent to revising the contents of previous judgments. However, the finality of the previous judgment remains intact. In conclusion, the Chiyu doctrine is problematic, both on doctrinal and statistical levels. First, on a doctrinal level, the abstract reviewability of the Mainland judgment under the procedure for trial supervision in Chiyu is not different from the American judgment in Nintendo. Retrials are also not in sharp contrast to appellate proceedings in terms of functions, procedures, and requirements. ${ }^{167}$ Second, the goal of refusing JRE - to make sure enforcement is not rendered invalid because the judgment on which it was based is reversed-is only rarely important because of the statistical infrequency of reversal. ${ }^{168}$ Therefore, it is unjustifiable to deny the recognition and enforcement of Mainland judgments merely because they are subject to retrial.

\section{Malicious Re-Litigations AND Forum SHOPPING CAUSED BY THE CHIYU DOCTRINE}

Because of the Chiyu doctrine, the judgments excluded by the narrow 2006 Mainland-Hong Kong Arrangement are unrecognizable and unenforceable in Hong Kong under common law. ${ }^{169}$ This has triggered malicious re-litigations (or parallel litigations) and forum shopping between Mainland China and Hong Kong. The two Lam Chit Man cases illustrate this point. ${ }^{170}$

Yat Cheong Electric Company ("Yat Cheong") was a Hong Kong company and owned by Lam Chit Man. ${ }^{171}$ Lam Chit Man I was between Lam Chit Man and Zhitao Lin. ${ }^{172}$ The latter was the legal representative of Dongguan Rong Feng Clocks \& Watches ("Rong Feng"), a Mainland company. ${ }^{173}$ Rong Feng and Yat Cheong concluded an oral lease agreement and agreed to rent one floor of the building located in Mainland China. However, the parties had several disputes

\footnotetext{
${ }^{167}$ Id. art. 186.

168 See supra notes 156,158 , and 160 and accompanying text.

169 See Huang, supra note 13, at 116-17 (commenting on the narrow scope of the Mainland-Hong Kong Arrangement).

${ }^{170}$ See, e.g., Lam Chit Man t/a Yat Cheong Electric Co. v. Lam Chi To, CACV 354/2001 (C.A. Dec. 18, 2001) (H.K.), available at http://legalref.judiciary.gov.hk/lrs/common/ju/ ju_frame.jsp?DIS $=61886 \&$ currpage $=T$; Lam Chit Man t/a Yat Cheong Electric Co. v. Cheung Shun Lin, CACV 1046/2001 (C.A. July 12, 2002) (H.K.), available at $\mathrm{http} / / /$ legalref.judiciary.gov.hk/lrs/common/ju/ju_frame.jsp?DIS=61890\&currpage=T.

${ }^{171}$ Lam Chit Man t/a Yat Cheong Electric Co. v. Lam Chi To, CACV 354/2001 (C.A. Dec. 18, 2001) (H.K.).

${ }^{172} I d$ ๆ 3.

${ }^{173} I d$. Dongguan is a city in Guangdong province Mainland China and it is very close to Hong Kong.
} 
during the performance of the agreement. ${ }^{174}$ Consequently, Rong Feng sued Yat Cheong in the Dongguan People's Court, ${ }^{175}$ and Yat Cheong sued Rong Feng in a Hong Kong court. ${ }^{176}$ The two actions proceeded almost in the same period of time in Hong Kong and Dongguan, but the Dongguan court rendered a judgment earlier than Hong Kong court. ${ }^{177}$ The winning party of the Dongguan judgment, Rong Feng, applied to the Hong Kong court seeking dismissal of the Hong Kong proceeding and for recognition of the Dongguan judgment. ${ }^{178}$

The key issue in Lam Chit Man I was whether the Dongguan judgment was final and should be recognized in Hong Kong. ${ }^{179}$ The Hong Kong Court of First Instance ruled that the Dongguan judgment was final and binding on both parties, which constituted an estoppel, and therefore both parties could not litigate the same cause of action in the Hong Kong

${ }^{174}$ Rong Feng claimed that Yat Cheong failed make his rent payments on time. Yat Cheong claimed that Rong Feng breached the agreement because Rong Feng did not provide the fire extinction certificate of the building and other government approval documents. Moreover, Rong Feng stopped water and electricity supply to the building without informing Yat Cheong in advance, unilaterally terminated the lease, and its staff beat Lam Chit Man when he moved out of the building. Id. $\uparrow 2$.

${ }^{175}$ Dongguan Rong Feng Biao Ye You Xian Gong Si v. Heng Chang Dian Zi (Shengzhen) You Xian Gong Si (Dongguan People's Ct. Nov. 13, 2000) (China).

${ }^{176}$ Lam Chit Man t/a Yat Cheong Electric Co. v. Lam Chi To, CACV 354/2001, 9 (C.A. Dec. 18, 2001) (H.K.).

177 To summarize the Dongguan action, on July 12, 1999, Rong Feng brought an action against Yat Cheong in Dongguan District People's Court claiming outstanding rents in Mainland China. Yat Cheong defended the substance of the case in Dongguan Court and brought a counter-action against Rong Feng claiming damages arising from breach of contract. Rong Feng defaulted in the last two hearings before the court issued the judgment. The Dongguan court ruled that based on the check issued by Yat Cheong, Yat Cheong had implicitly accepted the rents that Rong Feng asked for. The court found that the rents were reasonable and legal because it was a belowaverage price in the local lease market. Although Yat Cheong disputed with Rong Feng about the calculation of the rents, Yat Cheong failed to provide evidence for his argument. The court also held that although Yat Cheong argued that Rong Feng should compensate him for stopping water and electricity without advance notice, Yat Cheong failed to provide relevant evidence. Regarding the compensation for one of Rong Feng's employees beating Lam Chit Man, the court found that Lam Chit Man did not provide evidence for this claim. Moreover, the cause of action of this claim was tort, but the current case was based on breach of the lease agreement. Therefore, the court suggested that Lam Chit Man bring a tort action separately for the beating. The court also ruled that Rong Feng improperly terminated the lease contract unilaterally, but Yat Cheong voluntarily accepted this termination by moving his equipment out of the building after receiving the termination notice from Rong Feng. Consequently, on November 13, 2000, the Dongguan court rendered a judgment favourable to Rong Feng. At the end of the judgment, the court indicated that if a party was not satisfied with this judgment, it should appeal to the Dongguan Intermediate People's Court within 15 days after receiving this judgment. See also $i d$. 9 q 6-7.

${ }^{178}$ See Lam Chit Man t/a Yat Cheong Electric Co. v. Cheung Shun Lin, CACV 1046/2001, 9甲 1314 (C.A. July 12, 2002) (H.K.).

${ }^{179}$ Lam Chit Man t/a Yat Cheong Electric Co. v. Lam Chi To, CACV 354/2001, q甲 11-14 (C.A. Dec. 18, 2001) (H.K.). 
court. ${ }^{180}$ The Court of Appeals of Hong Kong disagreed. It first stated that under the precedent of Chiyu, if a Mainland procuratorate lodged a protest against a civil judgment, a relevant people's court had to retry the case and might reverse the judgment, so the Mainland judgment lacked finality and consequently could not be recognized or enforced in Hong Kong. ${ }^{181}$ The Hong Kong Court of Appeals acknowledged two differences between Lam Chit Man I and Chiyu. First, the Chiyu judgment was based on expert evidence about the procedure for trial supervision in Mainland law, but in Lam Chit Man I, no party provided evidence regarding Mainland law. ${ }^{182}$ Therefore, the Court did not know whether the current Mainland law regarding the procedure for trial supervision remained the same as when Chiyu was decided. ${ }^{183}$ Second, the Court noted that Lam Chit Man and Yat Cheong did not prove that they had taken any step to persuade a people's procuratorate to lodge a protest against the Mainland judgment. ${ }^{184}$ Nevertheless, the Court still ruled for Lam Chit Man and Yat Cheong because Rong Feng failed to prove that the Dongguan judgment was final. ${ }^{185}$

Lam Chit Man I demonstrates that if no party provides evidence of current Mainland law regarding the procedure for trial supervision, a Hong Kong court may not be able to apply the Chiyu doctrine. The reason is that the court does not know whether the current Mainland law regarding this procedure remains the same as when Chiyu was decided. This, to some extent, restricts the application of the Chiyu doctrine. Half a year later, in Lam Chit Man II, the Hong Kong Court of Appeals removed this restriction and held that in civil proceedings a previous decision on a question of foreign law can be deemed precedent and applied directly to later cases. ${ }^{186}$

The facts of Lam Chit Man II are similar to those of Lam Chit Man I. Yat Cheong and a Mainland company signed a lease for factory premises located in Mainland China. ${ }^{187}$ The parties had several disputes during the performance of the contract. The Mainland company sued Yat Cheong in the People's Court of Long Gang District. ${ }^{188}$ In contrast to

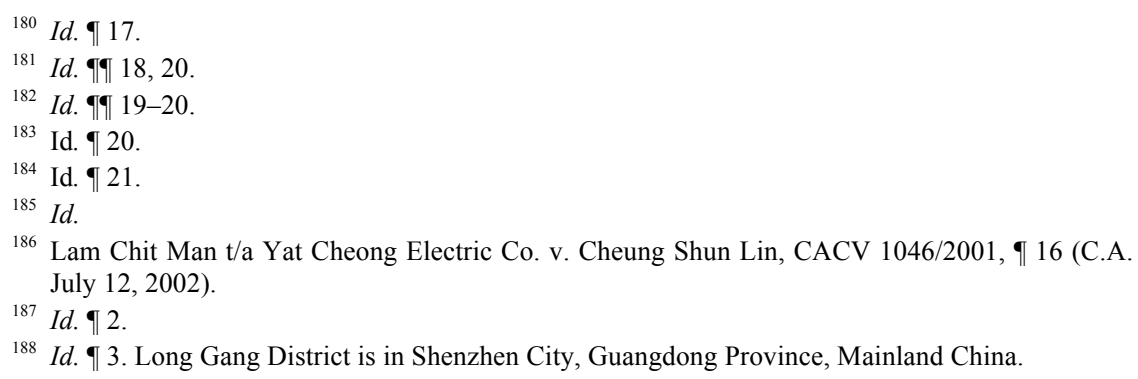


Lam Chit Man I, Yat Cheong did not defend itself in the Long Gang Court. On December 15, 2000, the Court made a judgment favorable to the Mainland company. Yat Cheong did not appeal to an intermediate people's court in due course, so the Long Gang judgment became final under Mainland law. ${ }^{189}$

On November 6, 2000, Yat Cheong brought an action against the Mainland company in front of a Master in Hong Kong for the same cause of action that had been decided in Long Gang Court. ${ }^{190}$ On January 16, 2001, the Master decided that unless Yat Cheong would successfully set aside the Long Gang judgment within 28 days, his claims should be dismissed because they had been decided by the Long Gang judgment. ${ }^{191}$ In other words, the Master recognized the Long Gang judgment; therefore, he held that Hong Kong court should not re-consider the claims that had been decided by the Mainland judgment. ${ }^{192}$ Yat Cheong appealed the Master's order to the Hong Kong Court of First Instance. ${ }^{193}$ The Court of First Instance held that it was improper for Hong Kong courts to exercise jurisdiction over this case for two reasons: first, all the disputes took place in Shenzhen City in Mainland China and the real estate in question was also located there; second, a court in Mainland China had made a judgment over the same cause of action. ${ }^{194}$

Yat Cheong appealed to the Court of Appeal in Hong Kong. The Court of Appeal reversed the judgment of the Court of First Instance and the Master's order. ${ }^{195}$ The Court held that, according to Chiyu, under the Mainland procedure for trial supervision, the people's court that renders a "final" judgment retains the power to reverse this judgment under some circumstances in the future, so the so-called "final" judgment is not final under Hong Kong law. ${ }^{196}$ The Court also held that foreign law should be deemed as facts in Hong Kong courts, and the decision or finding of a foreign law by a Hong Kong court could be used as an evidence of this foreign law in later cases, unless the contrary is proved. ${ }^{197}$ Therefore, the court held that the finding of the Mainland procedure for trial supervision in Chiyu should be applied to this case. In other words, because no

\footnotetext{
${ }^{189} I d .916$.

${ }^{190} I d$. $\mid 2$.

${ }^{191} I$ Id. $\uparrow 3$.

${ }^{192} I d$.

${ }^{193} \mathrm{Id}$.

${ }^{194} I d . \uparrow 12$.

${ }^{195} I d$ \ 930.

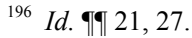

${ }^{197}$ Id. ศ⿻ 16-26.
} 
opposite evidence regarding Mainland law had been submitted, the Court of Appeal of Hong Kong assumed that the Mainland procedure for trial supervision has undergone no changes since Chiyu was decided in 1996. Therefore, the Court concluded that the Rong Gang judgment is not final and Hong Kong court can properly exercise jurisdiction over the case.

Notably, in both Lam Chit Man I and II, Yat Cheong never tried to bring a retrial himself or request a procuratorate to lodge a protest on his behalf in Mainland China, but the Hong Kong Court of Appeal holds that this is insufficient to make the Chiyu doctrine inapplicable to this case because Mainland law imposes no time limit for a procuratorate to lodge a retrial protest against a judgment.

A later case further illustrates Hong Kong courts' strong opinion about the universal applicability of the Chiyu doctrine: the Chiyu doctrine should be applied so that a Mainland judgment is not final, "unless and until it can be demonstrated to the satisfaction of the [Hong Kong] court that no such protest would be made by the relevant authority [in any time.]" 198 Therefore, debtors can succeed in Hong Kong enforcement proceedings by merely invoking the Chiyu doctrine even without making any efforts to initiate the Mainland procedure for trial supervision.

Moreover, Lam Chit Man I and II also demonstrate that the Chiyu doctrine encourages forum shopping. A Hong Kong party can sue its Mainland counterpart in Mainland China first. If it wins, it enforces the judgment in the Mainland; if it loses, it can bring an action against the same party in Hong Kong. For example, in Lam Chit Man I, Yat Cheong defended the merits of the case in a Mainland court but lost. Then it brought a case on the same cause of action against the winning party of the Mainland judgment in Hong Kong. The Hong Kong action was allowed to proceed. Therefore, Yat Cheong is allowed "two bites at the same apple." In Lam Chit Man II, Yat Cheong ignored the Mainland proceedings completely and concentrated on the Hong Kong proceedings, because as a Hong Kong company, suing in Hong Kong certainly gave it advantages. Overall, Yat Cheong conducted an obvious forum shopping - and succeeded!

Lam Chit Man I and II also vividly illustrate how the Chiyu doctrine encourages re-litigation (or parallel litigations) in Hong Kong. Permitting re-litigation might help parties to safeguard their rights and

\footnotetext{
${ }^{198}$ Cham Chow Yuen v. Nangyang Commercial Bank Tr. Ltd., HCAP 4/2002, 10 (C.F.I. June 7, 2004) (H.K.), available at http://legalref.judiciary.gov.hk/lrs/common/search/ search_result_detail_frame.jsp?DIS $=39889 \& Q \mathrm{QS}=\% 2 \mathrm{~B} \& \mathrm{TP}=\mathrm{JU}$.
} 
interests when the opposing party has assets available for enforcement that are located only in the place where the litigation is conducted. However, costs of re-litigation, the risks of inconsistent judgments, and the uncertainty of enforcement, will only worsen, instead of alleviate, disputes between parties. Neither Mainland China nor Hong Kong would recognize or enforce a sister-region judgment if it has rendered a judgment on the same cause of action. ${ }^{199}$ Therefore, in both Lam Chit Man I and II, neither Mainland judgments nor Hong Kong judgments would be recognized or enforced by the other side. Consequently, if Yat Cheong cannot find enough properties of the two Mainland companies in Hong Kong, it will not be able to satisfy its Hong Kong judgments. The disputes between them remain unresolved although tremendous amount of time and money has been spent on the litigations. This situation will discourage business between the two regions.

\section{The Preferable Minority APProACh in Hong Kong Courts}

Chiyu has not been unanimously accepted by all the judges in Hong Kong courts. Minority opinions may be more convincing. For example, in a forum non conveniens case, the plaintiff alleged that Mainland judgments were never final, and therefore Mainland courts were less convenient than Hong Kong courts. ${ }^{200}$ The Hong Kong court rejected this argument because this allegation was "blinkered and partial." ${ }^{201}$ The court further ruled that:

[the plaintiff's] criticisms against the Supervision Procedure in Mainland China amount to no more than a comparison between the Hong Kong system with the Mainland system and an invitation to the court to find that the local system is better than, or superior to, the Mainland system. This is precisely the sort of exercise which the court should not embark upon. ${ }^{202}$

This decision should be praised because imposing the Hong Kong criterion of finality to Mainland judgments results from an unjustifiable comparison of the two systems. Therefore, a judgment that is final and enforceable in Mainland China should be regarded as final in Hong Kong JRE proceedings.

\footnotetext{
199 Mainland-Hong Kong Arrangement, supra note 12, art. 9.6.

${ }^{200}$ New Link Consultants Ltd. v. Air China, [2004] H.K.C. 169, ๆ 93 (C.F.I.). This allegation was made by the plaintiff's legal aspect Professor Nanping Liu.

${ }^{201} I d$ ๆ 96

${ }^{202} \mathrm{Id}$.
} 
Li You Rong v. Li Rui Qiong is a 2004 case. ${ }^{203}$ It concerned whether a Mainland judgment was final if it was made by an appellate People's Court and affirmed in retrial. ${ }^{204}$ The dissenting judge in the Hong Kong Court of Appeal held that the Mainland judgment was final and should be recognized. ${ }^{205}$ In his view, Hong Kong courts should not deny JRE because of a theoretical likelihood that a retrial may be brought in Mainland China. ${ }^{206} \mathrm{He}$ held that after Mainland China adopted the policy of restricting retrials and of respecting the finality of judgments ${ }^{207}$ it was practically impossible for the judgment debtor in this case to bring the retrial again. ${ }^{208}$ However, the majority remanded the case partly on the procedural ground that the legal effects of the new Mainland policy were unclear. ${ }^{209}$ This dissenting opinion should be applauded because it is correctly based on the practical possibility of retrial in Mainland China, instead of the theoretical possibility adopted by the Chiyu doctrine.

\section{PROPOSED SOLUTIONS TO THE FINALITY CONFLICT}

There are three potential solutions to the finality dispute. The first two solutions require amending relevant regional laws in Hong Kong and Mainland China. The third solution involves two interregional law approaches. All of these potential solutions use the proposed Multilateral JRE Arrangement ${ }^{210}$ to fundamentally solve the finality dispute between Hong Kong and Mainland China.

\section{A. AMEND Hong Kong LAW}

The first solution would be for Hong Kong courts to abandon the Chiyu doctrine. The Mainland judgment in Chiyu should be treated as final until a court with competent jurisdiction orders the case retried and suspends the enforcement of the original judgment. ${ }^{211}$ Accordingly, the

\footnotetext{
203 Li You Rong, CACV 159/2004.

204 Id.

205 Id. $₫ 75$

206 Id.

207 For how this policy decreased retrials in Mainland China, see supra note 156 and accompanying text.

${ }^{208}$ Li You Rong, CACV 159/2004, $₫$ 66, 68, 69,75.

${ }^{209} I d$. $\|$ 27, 36.

210 A Multilateral JRE Arrangement between Mainland China, Hong Kong, and Macao is proposed by Huang to replace the Mainland-Hong Kong Arrangement and Mainland-Macao Arrangement and to ultimately realize free circulation of judgments in China. Huang, supra note 13, at 109-54.

211 See Mainland-Hong Kong Arrangement, art. 10. Professor Philip Smart prefers using the date that a Procuratorate lodges a protest as the time point when a judgment loses its finality. See Smart, supra note 100 , at 267 . However, there is a maximum thirty of days between when a
} 
Chiyu court should recognize and enforce the Mainland judgment and should stay the enforcement proceedings only when a Mainland court orders a retrial. ${ }^{212}$ If the retrial is conducted by the original court of first instance, the retrial judgment will be treated as a first instance judgment. Therefore, it will become final if appeal is not filed within fifteen days after the issuance of the judgment. ${ }^{213}$ If neither party timely appeals, this judgment should be treated as final so that it is recognizable and enforceable in Hong Kong. Moreover, if the retrial is conducted by the original second-instance court or any other higher courts, the retrial judgment should be treated as final when it is issued. Therefore, it would be recognizable and enforceable in Hong Kong. This suggestion can solve the finality dispute and help to enforce Mainland judgments in Hong Kong.

Alternatively, Professor Philip Smart recommended a way to change the judicial practice in Hong Kong regarding the recognition and enforcement of Mainland judgments:

The better approach, and one which it is submitted is fully justified by the common law authorities, would be to grant Order 14 judgment [summary judgment ${ }^{214}$ ] in favour of the plaintiff (except where, of course, the defendant raises genuine and substantial objections to enforcement, such as on the grounds of fraud or a denial of natural justice), but to stay or limit execution against the defendant's assets in Hong Kong. So that, in an appropriate case, money would be held in court and would not be paid out to the plaintiff until after the determination of any application for a retrial or attempt to invoke the supervisory jurisdiction of the Procuratorate. The possibility of repeated but groundless applications to the Procuratorate by a defendant could easily be provided for by appropriate undertakings on the part of the defendant or plaintiff. ${ }^{215}$

\section{B. AMEND THE MAINLAND CPL}

Procuratorate lodges a protest and a court orders to retry the case according to art. 188 of the Mainland CPL. See Mainland CPL, supra note 22, art. 188. Therefore, the time point that a judgment loses its finality should be when a court orders to retry the case.

${ }^{212}$ See Smart, supra note 100, at 267-68.

${ }^{213}$ Mainland CPL, supra note 22, art. 186.

${ }^{214}$ For Order 14 judgment, see CAmille CAmeron \& ElSa Kelly, Principles and Practice of Civil Procedure In Hong Kong 131-34, 331-32, 426 (2d ed. 2008).

${ }^{215}$ Smart, supra note 100, at 269. 
The second solution would be for Mainland China to revise its procedure for trial supervision and to forbid a judgment-rendering court from reopening its own judgments. This is because one key conflict between the Mainland procedure for trial supervision and the finality criteria under Hong Kong law is that the former permits the court that rendered a judgment to reopen the case either sua sponte or based on a procuratorate's or a party's requirement. ${ }^{216}$ For example, the Chiyu court emphasizes that the Mainland judgment is not final for the purpose of recognition and enforcement by Hong Kong courts because it "is not final and unalterable in the [Mainland] court which pronounced it." 217 The English precedent Gustave Nouvion also held that a final judgment should not be revisited by the court that pronounced it, and, in cases where the judgment is erroneous, the case should be reviewed by a higher court with jurisdiction to reopen the case. ${ }^{218}$

The 2007 Mainland CPL largely narrows the circumstances in which a judgment-rendering court may reopen its own judgment from three aspects. First, retrials generally should be conducted by a court higher than the judgment-rendering court. ${ }^{219} \mathrm{~A}$ judgment-rendering court should not conduct retrials when it has no jurisdiction over the case, the original trial was tainted by judicial corruption, or the original judgment was made by the Judicial Committee. ${ }^{220}$ This aims to make sure retrials are free of the defects that tainted the original trials, so the retrial judgments are more convincing for the parties. ${ }^{221}$ The newly added Article 181 of the Mainland CPL requires that when a retrial is commenced by parties' motion, the retrial should be conducted by an intermediate people's court or a people's court at a higher level. ${ }^{222}$ This provision forbids a district people's court from retrying its own judgments as long as the retrial is brought by a party. Second, the new Article 188 sets a default rule that if the retrial motion is submitted by a

\footnotetext{
${ }^{216}$ See supra note 76 and accompanying text.

${ }^{217}$ Chiyu Banking Corp. Ltd. v. Chan Tin Kwun, [1996] 2 H.K.L.R. 395 (H.C.).

${ }^{218}$ See Nouvion v. Freeman, [1889] 15 App. Cas. 1 (Eng.).

${ }^{219}$ Zuigao Renmin Fayuan Yinfa Guanyu Souli Minshi Zaishen Anjian de Ruogan Yijian de Tongzhi [Supreme People's Court's Notice on Accepting Civil Retrial Cases], art. 27, available at http://www.china.com.cn/policy/txt/2009-06/01/content_17863050.htm; Zuigao Renmin Fayuan Shixin Minshi Zaisheng Anjian Xingui Fuzheren Da Jizhe Wen [Supreme People's Courts' Answers to the Press Regarding the New Rules on Retrial in Civil Cases], available at http://www.zaishen.com/html/2011-04/506.htm. (last visited June 15, 2011) [hereinafter Answers].

${ }^{220}$ Interpretation of the Supreme People's Court on Several Questions of Applying the Procedure for Trial Supervision under the Civil Procedure Law, supra note 45, art. 29.

${ }^{221}$ See Answers, supra note 219.

${ }^{222}$ Mainland CPL, supra note 22, art. 181 ๆ 2.
} 
procuratorate, the court that rendered the original judgment shall not conduct retrials except in limited circumstances according to the law. ${ }^{223}$ Those circumstances are: new evidence is found; the facts which the original judgment is based on have no evidence to support; or the original judgment is based on forged evidence or un-cross-examined evidence. ${ }^{224}$ Third, under the 2007 Mainland CPL a judgment-rendering court cannot sua sponte reopen its own judgments, unless it finds a definite error in the judgment. ${ }^{225}$ If a judge finds a definite error in a judgment that he or she made, this judge should refer this case to the president of the court and the president must request permission from the adjudication committee to reopen the case. ${ }^{226}$ In conclusion, only in rare circumstances may a judgment-rendering court reopen its own judgment under the procedure for trial supervision under the $2007 \mathrm{CPL}$. There is currently no Hong Kong case law demonstrating that the 2007 CPL has soothed Hong Kong's concern regarding the finality of Mainland judgments. Therefore, Mainland China should consider explicitly and completely banning a judgment-rendering court from reopening its own judgments in any event. Retrials should be conducted by a court at the next higher level or a court at the same level, but in another district.

The Mainland-Hong Kong Arrangement has made the first effort in this direction. Article 2.2 of the Arrangement indicates that, "where a case is to be retried by a Mainland court in accordance with the law after an application for recognition and enforcement of the judgment in the same case has been filed with a Hong Kong court, the case shall be brought up for retrial by a people's court one level higher than the court which made the legally effective judgment." 227 Therefore, if a people's court reopens its own judgment, the retrial judgment cannot be recognized and enforced under the Arrangement. This provision also limits the retrials under Article 10 paragraph 2. ${ }^{228}$ Discouraging a judgment-rendering Mainland court from reopening its own judgments may also have other benefits. For example it may help guarantee a retrial judgment free from defects that may have tainted the original trial.

\footnotetext{
${ }^{223}$ Id. art. 188.

${ }^{224}$ Id. arts. $179,188$.

${ }^{225}$ Id. art. 177.

${ }^{226} \mathrm{Id}$.

${ }^{227}$ Mainland-Hong Kong Arrangement, supra note 12, art. 2.2 (emphasis added).

${ }^{228} I d$. art. 10 2. This provision indicates "[w] here a local people's court in Mainland China makes a decision of retrying a case for which a decision has been made, or where the Supreme People's Court makes such a decision, upon verification, a Hong Kong court may suspend the recognition and enforcement procedure, and resume the procedure if all or part of the decision is sustained after retrial, or terminate the procedure if the decision is completely overruled after retrial." $I d$.
} 
Mainland China should adopt a similar provision in the CPL to restrict a judgment-rendering Mainland court from reopening its own judgments. In this way, Mainland judgments may satisfy the finality requirement under Hong Kong law.

\section{INTERREGIONAL LAW APPROACHES}

\section{PROVIDE AN AUtONOMOUS TERMINOLOGY FOR FINALITY}

In order to avoid the finality dispute, the Mainland-Hong Kong Arrangement avoids words used by regional laws, namely, "legally effective" in the Mainland CPL 229 and the "final and conclusive" in the Hong Kong JRE law. ${ }^{230}$ Instead, it uses a new term, "enforceable final judgments," as a requirement for JRE. ${ }^{231}$ Three types of judgments are "enforceable final judgments" for the case of Mainland China: (1) any judgment rendered by the Supreme People's Court ${ }^{232}$ or an appellate court, ${ }^{233}(2)$ judgments where the time limit to appeal has expired and neither party has filed an appeal, ${ }^{234}$ (3) judgments rendered after the case is reviewed by the people's court at the next higher level in accordance with the procedure for trial supervision. ${ }^{235}$ In the case of Hong Kong, "enforceable final judgment" refers to any legally effective judgment rendered by the Court of Final Appeal, the Court of Appeals and the Court of First Instance of the High Court and the District Court. ${ }^{236}$ The Mainland implementing legislation uses the term "enforceable final judgments." ${ }^{237}$ However, the Hong Kong implementing legislation, the Mainland Judgments Ordinance, requires that "the judgment is final and conclusive as between the parties to the judgment; and the judgment is enforceable in the Mainland." ${ }^{238}$ A Hong Kong scholar asks whether the test of "enforceable and final" is the same as that of "final, conclusive, and enforceable." ${ }^{239}$ Although different opinions exist, ${ }^{240}$ this scholar

\footnotetext{
229 Mainland CPL, supra note 22, art. 141.

${ }^{230}$ Foreign Judgments (Reciprocal Enforcement) Ordinance, (1997) Cap. 319, 1, § 3(2)(a) (H.K.).

${ }^{231}$ Mainland-Hong Kong Arrangement, supra note 12, art. 2.

${ }^{232}$ Id. art. 2(1)(i).

${ }^{233} I d$. art. 2(1)(ii).

${ }^{234} I d$.

${ }^{235} I d$.

${ }^{236}$ Id. art. 2(2)

${ }^{237}$ The Mainland implementing legislation is identical to the Mainland-Hong Kong Arrangement, except for the statute of limitation.

${ }^{238}$ Foreign Judgments (Reciprocal Enforcement) Ordinance, (1997) Cap. 319, 1, § 5(2)(c)-(d) (H.K.).

${ }^{239}$ Zhang, supra note 71 , at $14-15$.
} 
believes these two tests are different. ${ }^{241}$ Therefore, the different wordings between the Arrangement and the Hong Kong implementing legislation have created confusion.

What brings more confusion is that the Mainland-Hong Kong Arrangement and Mainland-Macao Arrangement are not identical. Although the latter does not adopt the term "final judgment" because this term is not used by the regional laws in Mainland China and Macao, it uses "effective judgment" instead. Namely, only if a judgment is effective can it be recognized and enforced under the Arrangement. ${ }^{242}$ However, this Arrangement does not define "effective." Article 3 of the Arrangement indicates:

In respect to an effective judgment rendered by the court of one region and with the content of performance, the party involved can file an application for recognition and enforcement with the competent court of the other region. ${ }^{243}$

This seems to require the requested court to apply the law of the judgment-rendering region to determine whether the judgment is effective. However, the absence of an explicit definition of "effective" may possibly cause controversies in practice.

Considering that the criteria of finality adopted by Mainland China and Hong Kong are in a sharp contrast, and that the two Arrangements use different wording, the proposed Multilateral JRE Arrangement should provide uniformity. Arguably, the proposed Arrangement should avoid using any of the following terms that have been used in either regional or interregional laws: "enforceable final judgments," "legally enforceable judgments," "effective judgments," "final and conclusive judgments," or "definite judgments." It should create a new term and all implementing regional legislations should adopt this term. ${ }^{244}$ The following term ought to be considered: "qualified judgments under this Arrangement." Importantly, the term chosen should be an autonomous terminology.

\footnotetext{
${ }^{240}$ Madam Tsang of the Department of Justice took the view that under the Ordinance a mainland judgment is final and conclusive if falls into the enumerated list where no appeal is allowed or the time limit for appeal has expired or it is the decision of the second instance. This view seems to equate "finality" with "final judgment with enforceability." Id.

${ }^{241} I d$. at 15.

${ }^{242}$ Mainland-Macao Arrangement, supra note 12, art. 3.

${ }^{243} I d$.

${ }^{244}$ See Zhang, supra note 71, at 13-15 (explaining confusions arising from different terms used in the interregional arrangement and regional implementing legislations).
} 
An autonomous terminology refers to a terminology whose meaning is disengaged from the special understandings that might be associated with it under a regional law or an international legal instrument that a region ratified. ${ }^{245}$ In other words, the interpretation of a certain word or phrase in an interregional legal instrument should not depend on the law of one or more of the regions concerned, but, first and foremost, on the legal instrument itself. ${ }^{246}$ Using autonomous terminology to define terms or phrases in a legal instrument is a good solution to reconcile the differences between civil law and common law traditions. Autonomous terminology can prevent the instrument from being interpreted differently in different legal traditions, can increase certainty and predictability, simplify the interpretation process, and also ensure that the instrument will be applied in the way that it is intended to be applied. ${ }^{247}$ These benefits have been acknowledged by the European Court of Justice (ECJ) in numerous cases involving the Brussels Convention and Regulation. ${ }^{248}$

Similarly, the proposed Multilateral JRE Arrangement should adopt an autonomous terminology for "finality" in the arrangementmaking process. In implementation, regional courts should strictly adapt to the autonomous terminology and avoid the influences from regional laws. They should consult or seek coordination from the interregional mechanism that is established to facilitate interregional judicial assistance.

${ }^{245}$ Roger J. Goebel et al., CASes and Materials on European Union LaW 1390 (2d ed. 2002); see also Ulrich Magnus, Introduction, in BRUSSELS I REGULATION 31-32 (Ulrich Magnus \& Peter Mankowski eds., 2007). Magnus indicates that interpreting the Brussels Convention and Regulation by autonomous meanings has two aspects:

First, questions of doubt were principally to be answered without redress to a specific national law but from an insofar autonomous, to some extent supranational viewpoint.... [s]econdly, the construction of terms and the gapfilling of the Convention was to be inferred from the Convention itself generally also without any redress to other international legislative instruments.

Id. (internal citations omitted).

${ }^{246}$ See GoEBEL ET AL., supra note 245, at 1386.

${ }^{247}$ See Case C-29/76, LTU Lufttransportunternehmen GmbH \& Co. KG v. Eurocontrol, 1976 E.C.R. II-1541, 1556

${ }^{248}$ Magnus, supra note 245, at 31-33. Examples of autonomous interpretation can be found in Case C-125/92, Mulox IBC Ltd. v. Hendrick Geels, 1993 E.C.R. I-4075, I-4102 10; Case C-440/97, GIE Groupe Concorde v. Master of the vessel "Suhadiwarno Panjan," 1999 E.C.R. I-6307, I6347 9 11; Case C-271/00, Gemeente Steenbergen v. Luc Baten, 2002 E.C.R. I-10489, I-10519 28. Only a few exceptions to the autonomous interpretation exist. One is the place of performance, which can be interpreted according to the applicable national law. Case 12/76, Industrie Tessili Italiana Como v. Dunlop AG, 1976 E.C.R. 1473. 
Supposing that the term "qualified judgments under this arrangement" is chosen, it could be defined as follows:

\section{a. In Mainland China:}

1. a judgment rendered by the Supreme People's Court;

2. a judgment rendered by a higher people's court, an intermediate people's court or a district people's court, ${ }^{249}$ when appeal is not allowed for the first instance judgment or no appeal is made within the prescribed time limit, or an effective second-instance judgment; or

3. a retrial judgment rendered after the case is reviewed by the people's court other than the one rendered the previous judgment in accordance with the procedure for trial supervision.

b. In Hong Kong: a judgment rendered by the Court of Final Appeal, the Court of Appeal of the High Court, the Court of First Instance, or the District Court.

c. In Macao: a judgment rendered by the Court of Final Appeal, the Intermediate Court, or the Court of First Instance.

If a retrial occurs in Mainland China against a judgment that is under Hong Kong or Macao JRE proceedings, the Hong Kong or Macao court may suspend the proceedings, and resume it if all or part of the Mainland judgment is sustained after retrial, or terminate it if the Mainland judgment is completely overruled after retrial. If an appeal occurs in Hong Kong against a judgment that is under Mainland or Macao JRE proceedings, the Mainland or Macao court may suspend the proceedings, and resume it if all or part of the Hong Kong judgment is sustained after appeal, or terminate it if the Hong Kong judgment is completely reversed after appeal.

\section{APPLY THE LAW OF THE JUDGMENT-RENDERING REGION}

As an alternative to an autonomous terminology for finality, the proposed Multilateral JRE Arrangement may require a requested court to apply the law of the judgment-rendering region to determine the finality of a judgment. This lesson is drawn from U.S. law. ${ }^{250}$ Chinese regions may consider requiring a requested court to determine finality according to the law of the judgment-rendering region. If a retrial occurs in

\footnotetext{
249 The district people's courts could be restricted to those that have been delegated jurisdiction over the first instance of a civil or commercial case involving foreign, Hong Kong, Macao or Taiwanese affairs. See The Attachment of Mainland-Hong Kong Arrangement, supra note 12.

${ }^{250}$ See supra note 103 and accompanying text.
} 
Mainland China, requested courts in sister regions may suspend the recognition and enforcement proceedings upon the result of the Mainland retrial. If an appeal against a Hong Kong judgment has been filed, requested courts in sister regions may stay the recognition and enforcement proceedings upon the Hong Kong appeal. Applying the law of the judgment-rendering region can also solve the finality dispute. However, an autonomous terminology of finality brings more clarity and less need to look into sister-region laws. Therefore, it is preferable to applying the law of the judgment-rendering region.

\section{CONCLUSION}

The finality dispute between Mainland China and Hong Kong illustrates the conflicts between civil law and common law in JRE. Comparative studies between Hong Kong law, U.S. law, and EU law show that it is inappropriate to apply the law of the requested court to determine the finality of a judgment in the JRE proceedings. Statistics from 1999 to 2010 also demonstrate that the rates of retrials in Mainland China are not strikingly high. ${ }^{251}$ An in-depth reason for the finality dispute between Mainland China and Hong Kong is Hong Kong's concern regarding the quality of Mainland judgments. For example, after the conclusion of the Mainland-Hong Kong Arrangement, the Hong Kong business community expressed deep worries about exposing Hong Kong businessmen to judgments obtained through fraudulent means in Mainland courts. ${ }^{252}$ Mainland judicial integrity, the competence of courts, and difficulty in executing judgments have also been widely criticized in scholarship. ${ }^{253}$ Therefore, on the one hand, Mainland China and Hong Kong should make compromises by amending their own laws or

${ }^{251}$ See Randall Peerenboom, Judicial Accountability and Judicial Independence: An Empirical Study of Individual Case Supervision, 55 CHINA J. 67, 72 (2006), available at http://papers.ssrn.com/sol3/papers.cfm?abstract_id=1300840.

${ }^{252}$ Xianchu Zhang \& Philip Smart, Development of Regional Conflict of Laws: On the Arrangement of Mutual Recognition and Enforcement of Judgments in Civil and Commercial Matters between Mainland China and Hong Kong SAR, 36 H.K. L. J. 553, 578 (2006); see GRAEMe Johnston, The CONFLiCt OF LAWS IN HONG Kong 122 (2005).

${ }^{253}$ See, e.g., Vandekoolwyk, supra note 45 (discussing corruption in Chinese courts); Gerard J. Clark, An Introduction to the Legal Profession in China in the Year 2008, 41 SUFFOLK U. L. REV 833, 835-36 (2008) (pointing out the most serious challenge for rule of law in China is lack of judicial independence); Q.J. Kong, Enforcement of Hong Kong SAR Court Judgments in the People's Republic of China, 49 INT'L \& COMP. L.Q. 867, 870 (2000) (stating that in China administrative power dominates political and social affairs so judgment enforcement more reflects the interests of political and senior leaders' interests instead of those of legislators; therefore, judgment enforcement is often interfered with by politically influential parties); J.A. Cohen, Reforming China's Civil Procedure: Judging the Courts, 45 AM. J.COMP. L 793, 779-800 (1997). 
adopting an interregional law approach to solve the finality dispute. On the other hand, Mainland China should make serious efforts to improve its judicial system so as to help resolve conflicts in JRE between Mainland's civil law system and Hong Kong's common law system. 